\title{
A SUMMARY OF
}

\section{INDUSTRIAL ACCIDENTS}

\section{IN USAEC FACILTIES}

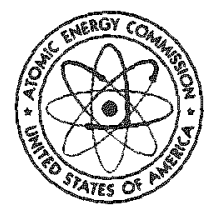

UNITED STATES ATOMIC ENERGY COMMISSION

Safery and Fire Protection Branch Office of Industrial Relations 


\section{DISCLAIMER}

This report was prepared as an account of work sponsored by an agency of the United States Government. Neither the United States Government nor any agency Thereof, nor any of their employees, makes any warranty, express or implied, or assumes any legal liability or responsibility for the accuracy, completeness, or usefulness of any information, apparatus, product, or process disclosed, or represents that its use would not infringe privately owned rights. Reference herein to any specific commercial product, process, or service by trade name, trademark, manufacturer, or otherwise does not necessarily constitute or imply its endorsement, recommendation, or favoring by the United States Government or any agency thereof. The views and opinions of authors expressed herein do not necessarily state or reflect those of the United States Government or any agency thereof. 


\section{DISCLAIMER}

Portions of this document may be illegible in electronic image products. Images are produced from the best available original document. 
-

0 


\section{PREFACE}

The accident experience in the U. S. Atomic Energy Commission contractor operations for the calendar years $1959-60$ is reported herein, as a third supplement to TID-5360 entitled, "A Summary of Accidents and Incidents Involving Radiation in Atomic Energy Activities, June 1945 through December 1955." The experience in 1956 was given in Supplement 1, and the experience in 1957-58 in Supplement 2.

Short narrative descriptions of incidents involving radioactive materials have been separated from the total accident experience, because of their special interest to the atomic energy industry. In some instances, the 1959-60 accidents have been added to the tables previously published in which were compiled data beginning in 1945. A new table of inadvertent criticality situations is included in this supplement through the courtesy of Mr. William Stratton of the Los Alamos Scientific Laboratory.

Also included in this supplement is a tabulation of exposure records at values from zero to 15 rems, which reflects a measure of the control of radiation in the work places in Commission operations. 


\section{CONTENTS}

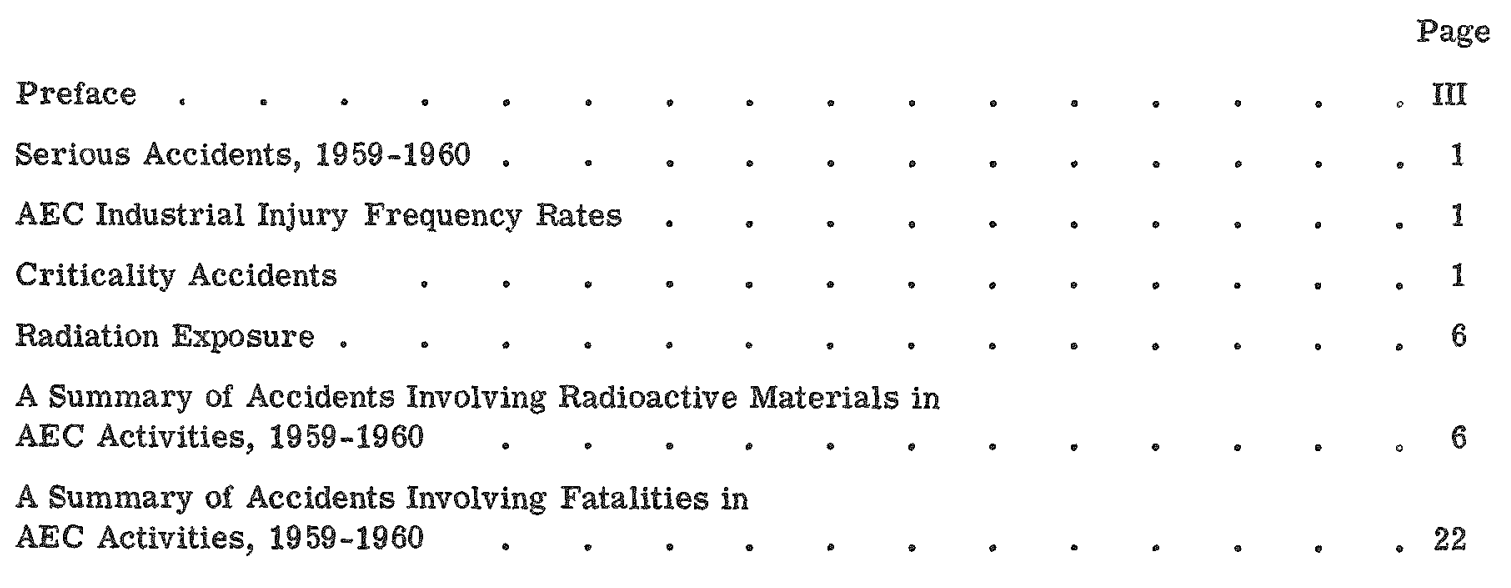

LIST OE TABLES AND CHARTS

1. Serious Accidents in AEC Facilities, 1959-1960, Table 1 .

2. AEC Industrial Injury Rates, 1947-1961, Chart 1

3. Criticality Accidents in AEC Facilities, Table 2

4. Exposures of Contractor Personnel to Penetrating Radiation, Summarized for 1959-1960, Table 3

5. Reported Radiation Accidents Resulting in Lost Time Injuries, Table 4

6. Fatal Injuries MED-AEC, Table 5

7. Death Rates AEC \& NSC, Chart 2 


\section{SERIOUS ACCIDENTS 1959 - 1960}

Serious accidents which occurred in atomic energy facilities, 1959 and 1960, inclusive, are summarized in Table 1. A "serious accident" means an accident required to be reported immediately to Commission Headquarters, and includes any of the following:

(a) fatalities;

(b) government property damage of $\$ 5,000$ or more;

(c) an external radiation exposure greater than 15 rems received over a short period of time; and

(d) other injury or industrial illness, no matter how slight, of five or more persons in one accident, and other defined accidents. (AEC Manual Chapters 0502-04 and 0523-052 give full definitions of immediately reportable accidents.)

\section{AEC INJURY FREQUENCY RATES}

The number of workers injured in 1960 was lower than in any year in AEC's history. (See Chart 1.) The lost time injury frequency for all AEC operations was 1.71 injuries per million man-hours worked, or $24 \%$ below the 1959 figure of 2.17 injuries per million man hours (see table below), and $13 \%$ below the previous best year of 1957 when the rate was 1.96 . While the construction rate was higher than in some previous years, the amount of construction work was less, and construction accident experience did not contribute largely to the over-all experience.

\section{AEC INDUSTRIAL INJURY FREQUENCY RATES}

\begin{tabular}{|c|c|c|c|}
\hline & 1959 & 1960 & \% Decrease \\
\hline Production & 1.14 & 0.73 & 36 \\
\hline Research & 1.97 & 1.57 & 20 \\
\hline Services & 3.05 & 2.30 & 25 \\
\hline Cost-Plus Construction & 4.64 & 4.23 & 9 \\
\hline Lump-Sum Construction & 16.72 & 13.35 & 20 \\
\hline Architect-Engineering & 2.05 & 1.48 & 28 \\
\hline Government & 2.14 & 0.69 & 68 \\
\hline All & 2.17 & 1.71 & 24 \\
\hline
\end{tabular}

\section{CRITICALITY ACCIDENTS IN USAEC FACILITIES}

Table 2 is adapted from a list prepared by W. R. Stratton, University of California, Los Alamos Scientific Laboratory, Los Alamos, New Mexico, in which he arranged criticality excursions according to systems. Accidents reported from countries other than the United States 
Table 1-SERIOUS ACCDENTS

USAEC Facilities, 1959-1960

\begin{tabular}{|c|c|c|c|c|}
\hline HS No.* & Date & Operations Office \& Contractor & Injury Loss & Remarks \\
\hline $59-1$ & 1-4-59 & SR-E. I. du Pont de Nemours \& Co. & $\$ 7,000$ & $\begin{array}{l}\text { Gasket on head of secondary condenser in unit failed, allowing hydro- } \\
\text { gen sulfide gas to flow into water side of heat exchanger. Relfef } \\
\text { valve vented open due to overpressure. 4-5 } \mathrm{T} \text { of gas released to } \\
\text { atmosphere. }\end{array}$ \\
\hline $59-2$ & $1-15-49$ & AL-Reynolde Electrical Engr. Co. & $\begin{array}{r}0 \\
\$ 20,000\end{array}$ & $\begin{array}{l}\text { Booms buckled on two } 50-T \text { cranes while lifting } 65 \mathrm{ft} \text { tower weighing } \\
38 \mathrm{~T} \text {. }\end{array}$ \\
\hline $59-3$ & 1-17-59 & OR- Union Carbide Nuclear Co. & $\$ 80$ & Multiple circuit breaker fallure led to severe electrical fire. \\
\hline 59-4 & 2-1-59 & AL-Bendix Aviation Corp. & $\begin{array}{r}0 \\
\$ 22,197\end{array}$ & $\begin{array}{l}\text { Dispatch oven failed when a power relay came loose from side of con- } \\
\text { trol box and dropped to bottom of unit. Weight of relay held arma- } \\
\text { ture and contects in closed position, energizing oven heaters. }\end{array}$ \\
\hline $59-5$ & 2-24-59 & AL-Univeraity of California (LASL) & $\begin{array}{l}2 \text { killed } \\
\$ 27,000\end{array}$ & Detonetion of explosives instantly killed 2 employees. (See page 22). \\
\hline $59-6$ & $3-25-59$ & SR-E. I. du Pont de Nemours \& Co. & $\$ 20,000$ & Leaking compression fitting. \\
\hline $59-7$ & 3-31-59 & HA-General Electric Co. & $\begin{array}{r}\text { 1st degree } \\
\text { burns-face } \\
\$ 9,518\end{array}$ & Plutonium glove box explosion. (See page 7). \\
\hline $59-8$ & 4-2-59 & SR-E. I. du Pont de Nemours \& Co. & $\$ 8,700$ & $\begin{array}{l}\text { Solvent transfer truck en route from } 200-\mathrm{H} \text { Area to plant burial } \\
\text { ground suddenly applied brakes at a rallroad orosing, causing } \\
\text { organic solvent containing intermediate level flssion product to } \\
\text { overflow into the shallow reservoir on top of truck tank, then ra- } \\
\text { diation solvent dripped onto road surface (0.9 mile). (See page 8). }\end{array}$ \\
\hline 59-9 & 4-2-59 & OR-Union Carbide Nuclear Co. & $\begin{array}{r}0 \\
\$ 7,485\end{array}$ & $\begin{array}{l}\text { During removal of obsolete ventilation ducts, duct was dropped and } \\
\text { snapped off a valve on the pump discharge side of coolant cooler. }\end{array}$ \\
\hline $59-10$ & $4-10-59$ & HA-General Electric Co. & 1 killed & Workman atraddling 4-in. pipe fell $59 \mathrm{ft}$. (See page 26). \\
\hline $59-11$ & 4-17-59 & OR-Union Carbide Nuclear Co. & $\begin{array}{r}0 \\
\$ 9,886\end{array}$ & Electric motor failure. \\
\hline $59-12$ & 4-17-59 & AL-Government-owned Property & $\$ 12,000$ & $\begin{array}{l}\text { Fire occurred in 1-story bedroom dwelling. The cause was com- } \\
\text { bustible materials in the vicinity of the floor furnace. }\end{array}$ \\
\hline 59-13 & 4-28-59 & OR-Union Carbide Nuclear Co. & $\begin{array}{r}0 \\
\$ 6,500\end{array}$ & Lightning damaged transformer. \\
\hline $59-14$ & $5-13-59$ & ID-Wright-Cheney-Birch & 1 killed & Employee was working on $60 \mathrm{ft}$ scaffold when it toppled. (See page 26). \\
\hline 59-15 & 5-13-59 & LAR-Pratt \& Whitney Aircraft (CANEL) & $\$ 30,000$ & $\begin{array}{l}\text { Electrical fire due to severe arcing on the line side of heater } \\
\text { breakers. }\end{array}$ \\
\hline $59-16$ & $6-3-59$ & SR-E. I. du Pont de Nemours Co. & $\begin{array}{r}0 \\
\$ 13,750\end{array}$ & Lightning damaged two 750 KVA transformers. \\
\hline $59-17$ & $7-1-59$ & AL-University of California (LASL) & $\begin{array}{r}2 \text { injured } \\
0\end{array}$ & $\begin{array}{l}\text { 3/4-in. copper tubing separated from male section of disconnect when } \\
\text { pressure was applied, loose end of tubing whipped around striking } \\
\text { and injuring } 2 \text { men. }\end{array}$ \\
\hline $59-18$ & 7-3-59 & SAN-University of California (LRL) & $\$ 32,000$ & $\begin{array}{l}\text { Overpressure helium system caused relesse and distribution of small } \\
\text { quantity of Curium-244, resulting in contamination of laboratory. } \\
\text { No overexposures. (See page 9). }\end{array}$ \\
\hline 59-19 & $7-17-59$ & AL- Univeraity of California (LASL) & $\$ 10,300$ & AA-Gas release (See page 10). \\
\hline $59-20$ & $7-18-59$ & HA-General Electric Co. & $\$ 24,500$ & $\begin{array}{l}\text { Fire involving bakery and grocery store. Electrical ahort in junction } \\
\text { box. }\end{array}$ \\
\hline 59-21 & $7-27-59$ & LAR-General Eleotric Co. & $\begin{array}{r}0 \\
\$ 9,540\end{array}$ & $\begin{array}{l}\text { Fire in construction contractor's material caused smoke and fire } \\
\text { damage to building. }\end{array}$ \\
\hline 59-22 & $7-31-59$ & HA-General Electric Co. & $\begin{array}{r}0 \\
\$ 4,000\end{array}$ & Autoclave explosion. \\
\hline 59-23 & $8-1-59$ & NY-Princeton University & $\$ 12,000$ & $\begin{array}{l}\text { Disruption of water service to stellarator caused by overpressure in } \\
\text { well pump supply line. }\end{array}$ \\
\hline 59-24 & $8-6-59$ & AL-Monsanto Chemical Co. & $\begin{array}{r}0 \\
\$ 1,933\end{array}$ & Drybox explosion. (See page 11). \\
\hline $59-25$ & $8-7-59$ & OR-J. A. Jones Construction Co. & 1 killed & $\begin{array}{l}\text { Electrician electrocuted when contacting energized frame of welding } \\
\text { machine. (See page 27). }\end{array}$ \\
\hline 59-26 & $8-16-59$ & CH-Atomica international & $\begin{array}{r}0 \\
\$ 24,450\end{array}$ & Sodium storage tank exploded. \\
\hline $59-27$ & $8-21-59$ & SR-E. I. du Pont de Nemours \& Co. & $\begin{array}{r}0 \\
\$ 129,324\end{array}$ & $\begin{array}{l}\text { Solution leaked from the loosened flange during maintenance work on } \\
\text { a waste evaporator in hot canyon, vaporized and contaminated a } \\
\text { crane. (See page 11). }\end{array}$ \\
\hline 59-28 & 9-4-59 & LAR-General Electric Co. & $\begin{array}{r}0 \\
\$ 7,500\end{array}$ & Wind damage to aluminum side wall of building. \\
\hline $59-29$ & 9-23-59 & SR-E. I. du Pont de Nemours \& Co. & $\$ 14,000$ & Product loss due to sudden leak at a high pressure valve. \\
\hline $59-30$ & $9-29-59$ & SR-E. I. du Pont de Nemours \& Co. & $\begin{array}{r}0 \\
\$ 50,000\end{array}$ & Hurricane damaged water dam. \\
\hline $59-31$ & 10-3-59 & SR-E. I. du Pont de Nemours \& Co. & $\begin{array}{r}0 \\
\$ 9,750\end{array}$ & Overheating caused diesel engine damage. \\
\hline $59-32$ & $10-14-59$ & AL-University of California (LASL) & 4 killed & $\begin{array}{l}\text { Explosion occurred while disposing of scrap and waste explosives. } \\
\text { (See page 28). }\end{array}$ \\
\hline $59-33$ & $10-16-59$ & ID-Phillips Petroleum Co. & $\begin{array}{r}0 \\
\$ 61,800\end{array}$ & Criticality incident, release of radioactive materials. (See page 12). \\
\hline $59-34$ & $10-30-59$ & $\begin{array}{l}\text { AL-B \& R Tub Co., subcontractor } \\
\text { Holmes \& Narver }\end{array}$ & $\begin{array}{r}0 \\
\$ 48,396\end{array}$ & Barge overturned carrying drill rig and core. \\
\hline $59-35$ & $10-30-59$ & SNR-General Electric Co. & $\begin{array}{l}1 \text { killedt } \\
\$ 100,000\end{array}$ & $\begin{array}{l}\text { Air-oil explosion occurred in air flask component of a } 3,000 \text { psi } \\
\text { hydraulic oil system. Fatality was not chargeable to AEC. }\end{array}$ \\
\hline 59-36 & $11-3-59$ & AL-Holmes \& Narver & $\begin{array}{r}0 \\
\$ 7,919\end{array}$ & IST atruck deep water pier during storm causing damage to pier. \\
\hline $59-37$ & $11-20-59$ & OR-Union Carbide Nuclear Co. & $\begin{array}{r}0 \\
\$ 350.000\end{array}$ & Chemical explosion in innercycle evaporator. (See page 13). \\
\hline
\end{tabular}

$\$ 350,000$ 
Table 1-SERIOUS ACCDENTS (Cont'd.)

\begin{tabular}{|c|c|c|c|c|}
\hline HS No.* & Date & Operations Office \& Contractor & Injury Loss & Remarks \\
\hline $59-38$ & $11-23-59$ & OR-Mallinckrodt Chemical Co. & $\$ \begin{array}{r}0 \\
\$ 6,000\end{array}$ & $\begin{array}{l}\text { Overheated flue in gas stack. Incident was probably caused by im- } \\
\text { proper combustion of propane gas or ignition of carbon which had } \\
\text { accumulated in some of the stacks. }\end{array}$ \\
\hline $59-39$ & $12-2-59$ & AL-Reynolds Electrical \& Engr. Co. & $\begin{array}{r}1 \text { killed } \\
0\end{array}$ & $\begin{array}{l}\text { An employee was killed instantly in head-on auto collision. (See } \\
\text { page 28). }\end{array}$ \\
\hline $59-40$ & $12-12-59$ & SR-E. I. du Pont de Nemours \& Co. & $\begin{array}{r}0 \\
\$ 5,200\end{array}$ & $\begin{array}{l}\text { Loose contaminated particles on the lid of a waste burial box were } \\
\text { scattered by the wind, contaminating the ground, locomotive and } \\
\text { spacer car. (See page 15). }\end{array}$ \\
\hline $59-41$ & $12-18-59$ & $\mathrm{CH}-\mathrm{Atomics}$ International & 1 killed & $\begin{array}{l}\text { Asphyxiation. Accident occurred at eodium pump loop when an in- } \\
\text { spector entered a pump casing which was } 15 \mathrm{ft} \text { deep and about } 40 \mathrm{fn} \text {. } \\
\text { in diameter to inspect the collar near the bottom. (See page } 29 \text { ). }\end{array}$ \\
\hline $59-42$ & $12-23-59$ & AL-Petroleum Combustion Engr. Co. & 1 killed & $\begin{array}{l}\text { Failure of a cable caused jib section of crane to fall and drop } 1 \text { cu. } \\
\text { yd. bucket of concrete on an employee of Petroleum Combustion \& } \\
\text { Engineering Co. (See page 32). }\end{array}$ \\
\hline $59-43$ & $12-29-59$ & OR-National Lead Co. of Ohto & $\begin{array}{r}0 \\
\$ 10,000+\end{array}$ & An explosion occurred in digester. \\
\hline $60-3$ & $1-16-60$ & CH-Argonne National Laboratory & $\$ 35,000$ & $\begin{array}{l}\text { Two boilers in a reactor power house exploded due to butldup of } \\
\text { fumes in firebox while an attempt was being made to start unit } \\
\text { manually. Damage primarily to boiler and adjacent plping with } \\
\text { minor building damage. }\end{array}$ \\
\hline $60-4$ & $1-29-60$ & AL-Holmes \& Narver & $\begin{array}{r}1 \text { killed } \\
0\end{array}$ & $\begin{array}{l}\text { Professional skin diver drowned while performing assigned duties at } \\
\text { the Pacific Proving Ground. (See page 31). }\end{array}$ \\
\hline $60-5$ & $2-12-60$ & CH-Argonne National Laboratory & $\$ 13,115$ & $\begin{array}{l}\text { A reactor vessel holddown plug assembly dropped when being lifted } \\
\text { and moved by means of a hand winch. Two riggers were Injured, } \\
\text { each having a fractured leg. The plug was damaged. }\end{array}$ \\
\hline $60-7$ & $3-3-60$ & SAN - University of California (LRL) & $\$ 12,500$ & $\begin{array}{l}\text { During the pressing of an experimental high explosive, a detonation } \\
\text { occurred. }\end{array}$ \\
\hline $60-8$ & $3-8-60$ & OR-Union Carbide Nuclear Co. & $\begin{array}{r}1 \text { overexposure } \\
0\end{array}$ & $\begin{array}{l}\text { An employee was exposed while cleaning up a cell due to the fallure } \\
\text { of the monitoring system to disclose the presence of radioactive } \\
\text { cerium-144. The exposure was } 5,550 \text { rads to the hand (bets dose). } \\
\text { (See page 16). }\end{array}$ \\
\hline $60-9$ & $1-29-60$ & OR-Union Carbide Nuclear Co. & $\$ 20,000$ & $\begin{array}{l}\text { Explosion occurred in a uranium sintering furnace located in a } \\
\text { foundry. Major structural damage to furnace and buildings. }\end{array}$ \\
\hline $60-10$ & $3-18-60$ & SR-E. I. du Pont de Nemours \& Co. & $\begin{array}{r}0 \\
\$ 135,300\end{array}$ & $\begin{array}{l}\text { A hydrogen-sulfide gas release from a process equipment condenser } \\
\text { caused a fire. The property damage was to the condenser. }\end{array}$ \\
\hline $60-11$ & $3-30-60$ & SR-E. I. du Pont de Nemours \& Co. & $\begin{array}{r}0 \\
\$ 6,000\end{array}$ & $\begin{array}{l}\text { During an electrical storm, lightning struck two } 200 \text {-hp pump motors } \\
\text { in an out-of-door pump pit. The cost was due to rewinding of the } \\
\text { burned out motors. }\end{array}$ \\
\hline $60-12$ & $3-18-60$ & AL-Reynolds Elec. \& Engr. Co. & $\begin{array}{r}1 \text { killed } \\
0\end{array}$ & $\begin{array}{l}\text { While helping to pour } 15 \text { gallons of hot soup stock into a steam kettle, } \\
\text { a kitchen employee slipped, causing hot soup to spill on his body, } \\
\text { resulting in first and second degree burns to chest and inside of } \\
\text { thighs-20\% of body. Employee died as a result of the buras. (See } \\
\text { page 32). }\end{array}$ \\
\hline $60-13$ & $4-13-60$ & NY - Harvard University & 1 killed & $\begin{array}{l}\text { While an employee was standing on a 34-inch-wide ground level wall, } \\
\text { straighteoing a reinforcing rod with a length of plpe, the rod broke, } \\
\text { and the employee fell } 20 \mathrm{ft} \text { to concrete suberea. (See page } 32 \text { ). }\end{array}$ \\
\hline $60-14$ & $4-17-60$ & HA-General Electric Co. & $\$ 250,443$ & $\begin{array}{l}\text { Fire and explosion in pyrophoric metal contents of a chemical dis- } \\
\text { solver caused high damage to dissolver, off-gas fliter, and related } \\
\text { process equipment. Contamination spread to cell, canyon, and } \\
\text { crane. The cause or causes of the accident are not established. } \\
\text { (See page 18). }\end{array}$ \\
\hline $60-15$ & $4-26-60$ & OR-Union Carbide Nuclear Co. & $\$ 39,500$ & $\begin{array}{l}\text { An irradiated graphite-clad reactor fuel element was being dry cut } \\
\text { inside a hot cell with a remotely operated saw. A change in air } \\
\text { pressure inside the cell forced contaminated graphite dust from the } \\
\text { cell, and it dispersed into the rest of the building. There were no } \\
\text { overexposures. The cost was due to cleanup of the area. (See } \\
\text { page 19). }\end{array}$ \\
\hline $60-16$ & 4-5-60 & SR-E. I. du Pont de Nemours \& Co. & $\begin{array}{r}0 \\
\$ 216,285\end{array}$ & $\begin{array}{l}\text { A leak in an outlet nozzle on a reactor necessitated a shutdown. The } \\
\text { leak was caused by three cracks extending approximately } 2 \frac{1}{2} \text { in. } \\
\text { around the circumference of the nozzle. The cost was chiefly due } \\
\text { to the repairing of the nozzle and the loss of heavy water. (See } \\
\text { page 17). }\end{array}$ \\
\hline $60-18$ & $6-15-60$ & AL-Reynolds Elec. \& Engr. Corp. & $\begin{array}{r}0 \\
\$ 9,950\end{array}$ & $\begin{array}{l}\text { A rigging crew was removing the astrodome from a } 20 \mathrm{ft} \text { camera } \\
\text { tower with a crane. As the dome was being lowered, the sling } \\
\text { brake, sllowing the dome to fall approximately } 10 \mathrm{ft} \text {. }\end{array}$ \\
\hline $60-19$ & $6-11-60$ & AL-General Electric Co. & $\begin{array}{r}0 \\
\$ 9,098\end{array}$ & $\begin{array}{l}\text { Fallure of overload switches to operate during severe electrical storm } \\
\text { caused burnout of transformer. }\end{array}$ \\
\hline $60-20$ & $6-24-60$ & D-Phillps Petroleum & 1 injured & $\begin{array}{l}\text { Employee seriously injured when portion of a atud (concrete anchor } \\
\text { nail) ricocheted, entering forehead over right eye and lodging in } \\
\text { brain, while using a powder-actuated power tool. }\end{array}$ \\
\hline $60-21$ & $6-28-60$ & OR-Goodyear Atomic Corp. & $\begin{array}{r}0 \\
\$ 7,145\end{array}$ & $\begin{array}{l}\text { The otainless steel lining of a new liquid nitrogen storage tank being } \\
\text { installed collapsed when its contents were partly evacuated during } \\
\text { an acceptance test. }\end{array}$ \\
\hline $60-22$ & $7-11-60$ & AL-Los Alamos Medical Center & $\begin{array}{r}0 \\
\$ 12,000\end{array}$ & $\begin{array}{l}\text { A } 15 \mathrm{KV} \text { switchgear located in a subbrasement equipment room was } \\
\text { damaged by fire. }\end{array}$ \\
\hline $60-23$ & $7-15-60$ & OR-Mallinckrodt Chemical Works & $\begin{array}{r}0 \\
\$ 5,000\end{array}$ & $\begin{array}{l}\text { Hydrogen gas explosion occurred in gas furnace enclosure in metal } \\
\text { plant. One employee suffered serious injuries. }\end{array}$ \\
\hline $60-24$ & $7-6-60$ & AL-Mound Laboratory & $\$ 31,360$ & $\begin{array}{l}\text { The accidental discherge of radioactive material into a room as a } \\
\text { result of pressure buildup in a drybox. This was due to an inlet } \\
\text { solenoid being locked in the open position and a venting solenoid } \\
\text { being closed due to a malfunction. The pressure built up to a point } \\
\text { that one of the drybox gloves blew out, thereby releasing radio- } \\
\text { gctive particulate material into the room. Eleven persone recelved } \\
\text { minor exposures. (See page 20). }\end{array}$ \\
\hline
\end{tabular}


Table 1-SERIOUS ACCDENTS (Cont'd.)

\begin{tabular}{|c|c|c|c|c|}
\hline HS No.* & Date & Operations Office \& Contractor & Injury \& Loss & Remarks \\
\hline $60-25$ & $8-31-60$ & DD-Fluor Corp., Ittd. & $\begin{array}{r}1 \text { killed } \\
0\end{array}$ & $\begin{array}{l}\text { While an employee was painting the handrails around a silo, he suf- } \\
\text { fered fatal injuries when he fell } 69 \mathrm{ft} \text {. (See page 33). }\end{array}$ \\
\hline $60-26$ & $9-13-60$ & SR-E. I. du Pont de Nemoure Co. & $\$ \begin{array}{r}0 \\
\$ 250,000\end{array}$ & $\begin{array}{l}\text { Contaminated cooling water discharged from canyon onto floor. No } \\
\text { overexposures. The large loss was due to decontamination. (See } \\
\text { page 20). }\end{array}$ \\
\hline $60-27$ & $9-29-60$ & SR-E. I. du Pont de Nemours \& Co. & $\begin{array}{r}0 \\
\$ 8,300\end{array}$ & $\begin{array}{l}\text { Water leaking through roof during heavy rainstorm damaged trans- } \\
\text { former. }\end{array}$ \\
\hline $60-28$ & $6 / 2-6-60$ & SR-E. I. du Pont de Nemours \& Co. & $\begin{array}{r}0 \\
\$ 24,000\end{array}$ & $\begin{array}{l}\text { During shipment of Irradiated fuel elements, } 30 \text { to } 40 \text { gallons of con- } \\
\text { taminated water leaked from the cask. The cost was due to decon- } \\
\text { tamination of area. (See page 19). }\end{array}$ \\
\hline $60-29$ & $8-4-60$ & OR-Goodyear Atomic Corp. & $\$ 18,132$ & $\begin{array}{l}\text { During violent storm, severe power system disturbance caused oil } \\
\text { circuit breaker failure. }\end{array}$ \\
\hline $60-30$ & $10-7-60$ & AL-Sandia Corp. & $\begin{array}{r}0 \\
\$ 16,500\end{array}$ & $\begin{array}{l}\text { Beechcraft Drone Aircraft, which was to be used for air sampling, } \\
\text { crashed when radio control was lost in desert. }\end{array}$ \\
\hline 60-31 & $11-8-60$ & AL-Sandia Corp. & 2 exposures & $\begin{array}{l}\text { Employees were accidentally exposed to electron beam emanating } \\
\text { from a Van de Graaff accelerator. (See page } 21 \text { ). }\end{array}$ \\
\hline $60-32$ & $9-13-60$ & LAR-General Electric Co. & $\$ 12,000$ & During an electrical storm lightning damaged transformer. \\
\hline $60-33$ & $7-12-60$ & HA-Government-Hanford & $\begin{array}{r}0 \\
\$ 6,000\end{array}$ & $\begin{array}{l}\text { 15-mile per hour breeze spread a grass fire over } 3,000 \text { acres of } \\
\text { AEC property. }\end{array}$ \\
\hline $60-34$ & $11-2-60$ & SR-E. I. du Pont de Nemours \& Co. & $\$ 37,100$ & Fire in a construction butlding. \\
\hline $60-35$ & $11-10-60$ & SAN-University of California (LRL) & $\$ 101,000$ & $\begin{array}{l}\text { Fire started in curium processing cave by an apparent overheating of } \\
\text { oil bath in glove box. Loss confined to one room, but all contents } \\
\text { complete loss. No release of radioactive materials to environment. }\end{array}$ \\
\hline $60-36$ & $11-10-60$ & SR-E. I. du Pont de Nemours \& Co. & $\begin{array}{r}0 \\
\$ 40,000\end{array}$ & Induced draft fan failed due to excessive vibration. \\
\hline $60-37$ & $11-14-60$ & AL-Sandia Corp. & $\begin{array}{r}0 \\
\$ 32,000\end{array}$ & Fire occurred in heat paper stored in dry room. \\
\hline $60-38$ & $12-7-60$ & OR-Union Carbide Nuclear Co. & $\begin{array}{r}0 \\
\$ 10,036\end{array}$ & $\begin{array}{l}\text { A full, high pressure, } 30 \text {-tube gas trailer overturned in the process } \\
\text { of coupling to tractor. }\end{array}$ \\
\hline $60-39$ & $11-18-60$ & HA-General Electric Co. & 1 injured & Pipefitter slipped and fell $15 \mathrm{ft}$ down a shaft (in critical condition). \\
\hline $60-40$ & $12-21-60$ & HA-General Electria Co. & $\$ 12,294$ & $\begin{array}{l}\text { Build-up of pressure in a steam autoclave resulted in a blow-off } \\
\text { which sent some material from the autoclave through the building } \\
\text { roof. No radiation resulted. }\end{array}$ \\
\hline $60-41$ & $10-4-60$ & AL-Edgerton, Germeshausen \& Grier & $\begin{array}{r}2 \text { exposures } \\
0\end{array}$ & Two employees were exposed to gamma radiation. (See page 21). \\
\hline $60-42$ & $11-17-60$ & OR-Union Carbide Nuclear Co. & $\$ 103,260$ & Ten ton cylinder of $\mathbf{U F}_{6}$ ruptured. \\
\hline $60-43$ & $11 / 8-28-60$ & OR-National Lead Co. of Ohio & $\$ 5,000+$ & $\begin{array}{l}\text { Slightly enriched uranium tetrafluoride lost through stack of dust } \\
\text { collector located in the plant. }\end{array}$ \\
\hline
\end{tabular}

* Office of Operational Safety, USAEC Headquarters, File Number. † Navy personnel.

\section{AEC INDUSTRIAL INJURY RATES} $1947-1961$

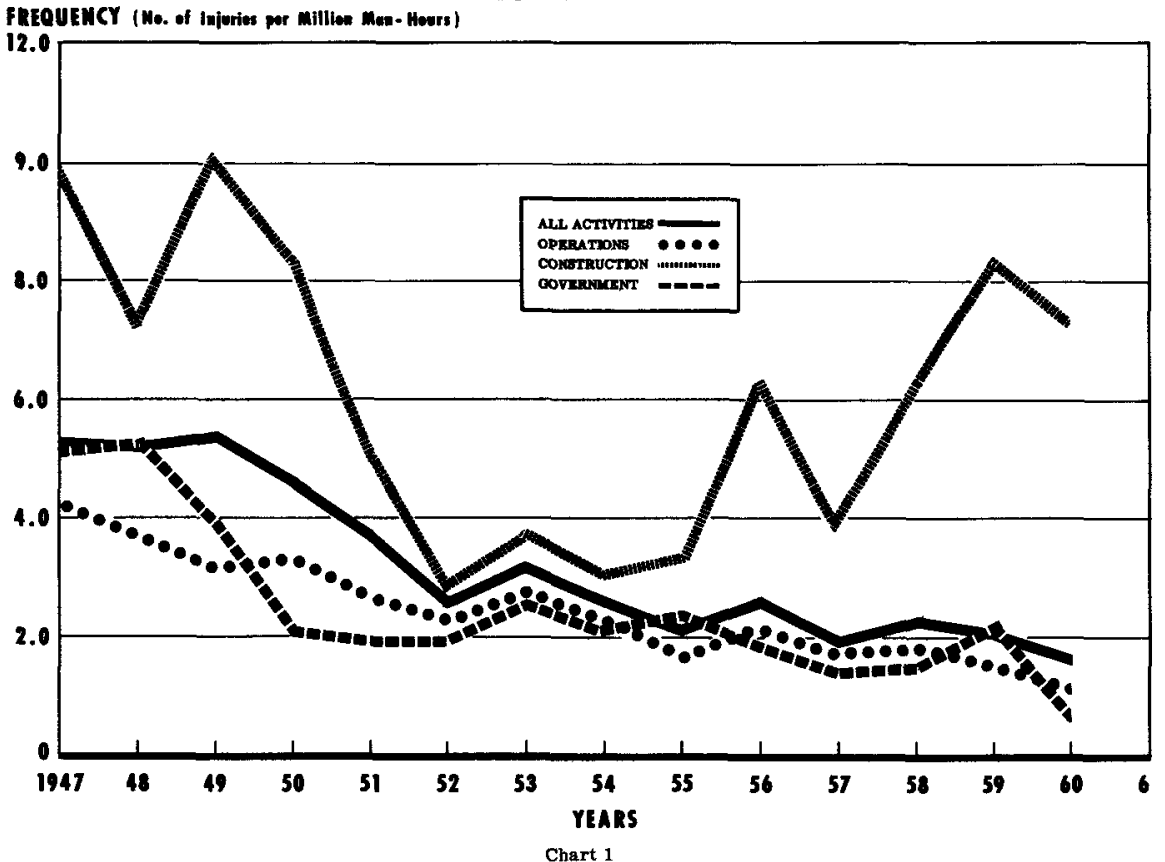


Table 2-CRITICALITY ACCIDENTS IN USAEC FACILITIES*

\begin{tabular}{|c|c|c|c|c|c|c|}
\hline Date & Location & Active Material & Geometry & Total Fissions & Cause & Physical Damage \\
\hline \multicolumn{7}{|c|}{ Metal Systems In Air } \\
\hline Aug. 21, 1945 & Los Alamos, New Mexico & $\begin{array}{l}6.2 \mathrm{Kg} \\
\delta \text {-phase } \mathrm{Pu}\end{array}$ & $\begin{array}{l}\text { Spherical core } \\
\text { tungsten- } \\
\text { carbide } \\
\text { reflected }\end{array}$ & $\sim 10^{16}$ & $\begin{array}{l}\text { Hand stacking } \\
\text { reflector }\end{array}$ & None \\
\hline May 21, 1946 & Los Alamos, New Mexico & $\begin{array}{l}6.2 \mathrm{Kg} \\
\delta \text {-phase Pu }\end{array}$ & $\begin{array}{r}\text { Spherical core } \\
\text { Be reflected }\end{array}$ & $\sim 3 \times 10^{15}$ & $\begin{array}{l}\text { Hand stacking } \\
\text { reflector }\end{array}$ & None \\
\hline Apr. 18, 1952 & $\begin{array}{l}\text { The Los Alamos Scientific } \\
\text { Lab., New Mexico }\end{array}$ & $\begin{array}{l}92.4 \mathrm{Kg} \text { uranium } \\
\text { metal, } 93 \% \mathrm{U}-235\end{array}$ & $\begin{array}{l}\text { Cylinder } \\
\text { unreflected }\end{array}$ & $1.5 \times 10^{16}$ & $\begin{array}{l}\text { Computation } \\
\text { error }\end{array}$ & None \\
\hline Feb. 3, 1954 & $\begin{array}{l}\text { The Los Alamos Scientific } \\
\text { Lab., New Mexico }\end{array}$ & $\begin{array}{l}53 \mathrm{Kg} \text { uranium } \\
\text { metal, } 93 \% \mathrm{U}-235\end{array}$ & $\begin{array}{l}\text { Sphere } \\
\text { unreflected }\end{array}$ & $5.6 \times 10^{16}$ & $\begin{array}{l}\text { Incorrect } \\
\text { operation }\end{array}$ & $\begin{array}{l}\text { Slight warping of } \\
\text { pieces }\end{array}$ \\
\hline Feb. 12, 1957 & $\begin{array}{l}\text { The Los Alamos Scientific } \\
\text { Lab., New Mexico }\end{array}$ & $\begin{array}{l}54 \mathrm{Kg} \text { uranium } \\
\text { metal, 93\% U-235 }\end{array}$ & $\begin{array}{l}\text { Sphere } \\
\text { unreflected } \\
\text { except for } \\
\text { experiment }\end{array}$ & $1.2 \times 10^{19}$ & $\begin{array}{l}\text { Shift of } \\
\text { experiment }\end{array}$ & $\begin{array}{l}\text { Warping, oxidation } \\
\text { near melting close } \\
\text { to center }\end{array}$ \\
\hline \multicolumn{7}{|c|}{ Solution Systems } \\
\hline Dec., 1949 & $\begin{array}{l}\text { The Los Alamos Scientific } \\
\text { Lab., New Mexico }\end{array}$ & $\begin{array}{l}\sim 1 \mathrm{Kg} \mathrm{U}-235 \\
\mathrm{UO}_{2}\left(\mathrm{NO}_{\mathrm{g}}\right)_{2} \text { in } \\
13.6 \text { liters } \\
\text { water }\end{array}$ & $\begin{array}{l}\text { Sphere } \\
\text { graphite } \\
\text { reflected }\end{array}$ & $3-4 \times 10^{16}$ & $\begin{array}{l}\text { Manual withdrawal } \\
\text { of two poison } \\
\text { control rods }\end{array}$ & None \\
\hline Nov. 16, 1951 & $\begin{array}{l}\text { The Hanford Works, } \\
\text { Richland, Washington }\end{array}$ & $\begin{array}{l}1.15 \mathrm{Kg} \mathrm{Pu} \\
\mathrm{PuO}_{2}\left(\mathrm{NO}_{3}\right)_{2} \text { in } \\
63.8 \text { liters water }\end{array}$ & $\begin{array}{l}\text { Sphere } 93 \% \\
\text { full } \\
\text { unreflected }\end{array}$ & $8 \times 10^{16}$ & $\begin{array}{l}\text { Poison control } \\
\text { rod run out too } \\
\text { fast }\end{array}$ & None \\
\hline May 26, 1954 & $\begin{array}{l}\text { The Oak Ridge National } \\
\text { Lab., Tennessee }\end{array}$ & $\begin{array}{l}18.3 \mathrm{Kg} \mathrm{U}^{235} \\
\mathrm{UO}_{2} \mathrm{~F}_{2} \text { in } 55.4 \\
\text { liters water }\end{array}$ & $\begin{array}{l}\text { Cylindrical } \\
\text { annulus } \\
\text { unreflected }\end{array}$ & $1 \times 10^{17}$ & $\begin{array}{l}\text { Tilting of inner } \\
\text { poison cylinder }\end{array}$ & None \\
\hline Feb. 1, 1956 & $\begin{array}{l}\text { The Oak Ridge National } \\
\text { Lab., Tennessee }\end{array}$ & $\begin{array}{l}27.7 \mathrm{Kg} \mathrm{U}^{295} \\
\mathrm{UO}_{2} \mathrm{~F}_{2} \text { in } 58.9 \\
\text { liters water }\end{array}$ & $\begin{array}{l}\text { Cylinder } \\
\text { unreflected }\end{array}$ & $1.6 \times 10^{17}$ & $\begin{array}{l}\text { Falling scram set } \\
\text { up waves creating } \\
\text { a critical geometry }\end{array}$ & $\begin{array}{l}\text { Warping of bottom } \\
\text { of cylinder }\end{array}$ \\
\hline June 16,1958 & $\begin{array}{l}\text { Y-12 Processing Plant, } \\
\text { Oak Ridge, Tennessee }\end{array}$ & $\begin{array}{l}2.5 \mathrm{Kg} \mathrm{v}^{236} \\
\mathrm{UO}_{2}\left(\mathrm{NO}_{3}\right)_{2} \text { in } \\
56 \text { liters water }\end{array}$ & $\begin{array}{l}\text { Cylinder } \\
\text { concrete } \\
\text { reflected below }\end{array}$ & $1.3 \times 10^{18}$ & $\begin{array}{l}\text { Wash water added } \\
\text { to } \mathrm{UO}_{2}\left(\mathrm{NO}_{3}\right)_{2} \\
\text { solution }\end{array}$ & None \\
\hline Dec. 30,1958 & $\begin{array}{l}\text { The Los Alamos Scientific } \\
\text { Lab., New Mexico } \\
\text { Pu Processing Plant }\end{array}$ & $\begin{array}{l}3.27 \mathrm{Kg} \mathrm{Pu} \\
\mathrm{PuO}_{2}\left(\mathrm{NO}_{3}\right)_{2} \text { in } \\
\sim 168 \text { liters } \\
\text { water }\end{array}$ & $\begin{array}{l}\text { Cylinder water } \\
\text { reflected } \\
\text { below }\end{array}$ & $1.5 \times 10^{17}$ & $\begin{array}{l}\text { Agitator created } \\
\text { a critical } \\
\text { geometry }\end{array}$ & None \\
\hline Oct. 16, 1959 & $\begin{array}{l}\text { Chemical Processing Plant, } \\
\text { Idaho Reactor Testing } \\
\text { Area }\end{array}$ & $\begin{array}{l}34.5 \mathrm{Kg} \mathrm{U}^{235} \\
\sim 800 \text { liters } \\
\mathrm{UO}_{2}\left(\mathrm{NO}_{3}\right)_{2} \text { water }\end{array}$ & $\begin{array}{l}\text { Cylinder } \\
\text { concrete } \\
\text { reflected below }\end{array}$ & $\sim 4 \times 10^{18}$ & $\begin{array}{l}\text { Solution siphoned } \\
\text { from safe to } \\
\text { unsafe geometry }\end{array}$ & None \\
\hline Jan. 25, 1961 & $\begin{array}{l}\text { Chemical Processing Plant, } \\
\text { Idaho Reactor Testing } \\
\text { Area }\end{array}$ & $\begin{array}{l}8 \mathrm{Kg} \mathrm{U} \\
\mathrm{UO}_{2}\left(\mathrm{NO}_{3}\right)_{2} \text { in } \\
40 \text { liters } \\
\text { water }\end{array}$ & Cylinder & $6 \times 10^{17}$ & $\begin{array}{l}\text { Solution pumped } \\
\text { from safe to } \\
\text { unsafe geometry }\end{array}$ & None \\
\hline \multicolumn{7}{|c|}{ Inhomogeneous Water Moderated Systems } \\
\hline June 4, 1945 & Los Alamos, New Mexico & $\begin{array}{l}35.4 \mathrm{Kg} \text { uranium } \\
\sim 83 \% \text { v } \mathrm{v}^{235} \\
1 / 2-i \mathrm{in}, \text { cubes }\end{array}$ & $\begin{array}{l}\text { Pseudosphere } \\
\text { water } \\
\text { reflected }\end{array}$ & $\sim 3 \times 10^{16}$ & $\begin{array}{l}\text { Water seeping } \\
\text { between blocks }\end{array}$ & None \\
\hline Feb. 1, 1951 & $\begin{array}{l}\text { The Las Alamos Scientific } \\
\text { Lab., New Mexico }\end{array}$ & $\begin{array}{l}2 \text { cylinders } \\
\text { uranium } 24.4 \text { and } \\
38.5 \mathrm{Kg} 93 \% \mathrm{U}^{235}\end{array}$ & $\begin{array}{l}2 \text { cylinders } \\
\text { water } \\
\text { reflected }\end{array}$ & $10^{17}$ & $\begin{array}{l}\text { Scram increased } \\
\text { reactivity }\end{array}$ & Slight oxidation \\
\hline June 2,1952 & The Argonne National Lab. & $\begin{array}{l}6.8 \mathrm{Kg} \mathrm{U}^{235} \\
\text { oxide particles } \\
\text { in plastic }\end{array}$ & $\begin{array}{l}\text { Inhomogeneous } \\
\text { cylinder water } \\
\text { reflected }\end{array}$ & $1.22 \times 10^{17}$ & $\begin{array}{l}\text { Manual withdrawal } \\
\text { of central safety } \\
\text { rod }\end{array}$ & Plastic destroyed \\
\hline July 22,1954 & $\begin{array}{l}\text { The Reactor Testing Area, } \\
\text { Idaho Falls, Idaho }\end{array}$ & $\begin{array}{l}\text { U-Al plates } \\
\text { clad with Al }\end{array}$ & $\begin{array}{l}\text { Inhomogeneous } \\
\text { cylinder water } \\
\text { moderated }\end{array}$ & $4.68 \times 10^{18}$ & $\begin{array}{l}\text { Estimate of } \\
\text { expected excursion } \\
\text { too low }\end{array}$ & Reactor destroyed \\
\hline Jan. 3,1961 & $\begin{array}{l}\text { Idaho Reactor Testing } \\
\text { Area }\end{array}$ & $\begin{array}{l}\text { U-Al plates } \\
\text { clad with } \mathrm{Al}\end{array}$ & $\begin{array}{l}\text { Inhomogeneous } \\
\text { cylinder water } \\
\text { moderated }\end{array}$ & $1.5 \times 10^{18}$ & Not determined & Extensive to resctor \\
\hline \multicolumn{7}{|c|}{ Miscellaneous Systems } \\
\hline Feb. 11, 1945 & Los Alamos, New Mexico & $\begin{array}{l}\mathrm{UH}_{8} \text { pressed in } \\
\text { styrex }\end{array}$ & Cylinder & $\sim 6 \times 10^{15}$ & $\begin{array}{l}\text { Reflector added } \\
\text { and/or source } \\
\text { too large }\end{array}$ & $\begin{array}{l}\mathrm{UH}_{3} \text {-styrex cubes } \\
\text { swollen and } \\
\text { blistered }\end{array}$ \\
\hline Nov. 29,1955 & $\begin{array}{l}\text { Idaho Reactor Testing } \\
\text { Area }\end{array}$ & $1 / 2-$ in. $U^{235} \operatorname{rods}$ & $\begin{array}{l}\text { Cylinder, rods } \\
\text { cooled by } \mathrm{NaK}\end{array}$ & $4.7 \times 10^{17}$ & $\begin{array}{l}\text { Incorrect scram } \\
\text { used }\end{array}$ & Core molten \\
\hline July 3,1956 & $\begin{array}{l}\text { The Los Alamos Scientific } \\
\text { Lab., New Mexico }\end{array}$ & $\begin{array}{l}58 \mathrm{Kg} \text { uranium } \\
93 \% \mathrm{U}^{235}, 2 \text { and } \\
5 \mathrm{mil} \text { foils }\end{array}$ & Cylinder & $3.2 \times 10^{16}$ & $\begin{array}{l}\text { Too rapid } \\
\text { assembly }\end{array}$ & None \\
\hline
\end{tabular}

* For additional information on these accidents, see previous TD-5360 series and "A Review of Criticality Accidents" by W. R. Stratton, University of California (LASL). 
have been omitted from his original list. Only criticality accidents in AEC contractor plants are listed.

\section{RADIATION EXPOSURE OF AEC CONTRACTOR PERSONNEL}

In the course of their work, some employees at atomic energy installations may receive exposure to radiation. This is kept to a minimum consistent with the benefits to be derived. A survey of the Commission's contractor employees showed that of the more than 75,000 contractor employees monitored in 1959 and 82,000 employees in $1960,99.9$ per cent received less than 5 rems within the year and that 94.5 per cent received only one rem or less. These exposures are well within the limits defined for atomic energy contractor workers. Table 3 gives details for the two years.

Table 3-EXPOSURES OF CONTRACTOR PERSONNEL TO PENETRATING RADIATION, SUMMARIZED FOR 1959 and 1960

\begin{tabular}{ccc}
\hline $\begin{array}{c}\text { Range of Annual } \\
\text { Total Exposure } \\
\text { in Rems* }\end{array}$ & $\begin{array}{c}1960 \\
\text { No. of Employees }\end{array}$ & $\begin{array}{c}1959 \\
\text { No. of Employees }\end{array}$ \\
\hline $0-1$ & 77,522 & 71,600 \\
$1-2$ & 2,828 & 2,584 \\
$2-3$ & 1,405 & 979 \\
$3-4$ & 283 & 236 \\
$4-5$ & 113 & 113 \\
$5-6$ & 24 & 29 \\
$6-7$ & 10 & 16 \\
$7-8$ & 3 & 11 \\
$8-9$ & 2 & 5 \\
$9-10$ & 2 & 5 \\
$10-11$ & 2 & 1 \\
$11-12$ & 0 & 0 \\
$12-13$ & 0 & 1 \\
$13-14$ & 0 & 0 \\
$14-15$ & 0 & 0 \\
15 plus & $3 \dagger$ & $1 \dagger$ \\
\hline
\end{tabular}

* The rem is a measure of the dose of any ionizing radiation to body tissues in terms of its estimated biological effect relative to a dose of one roentgen of high voltage $x$-rays.

† See HS-59-103, page 6; HS-60-31, page 21; HS-60-41, page 21.

\section{ACCIDENTS INYOLVING RADIOACTIYE MATERIAL IN ATOMIC ENERGY ACTIVITIES 1959 - 1960}

The following descriptions add details to accidents involving radiation, already listed as accidents in Table 1, and report a few others of less concern.

\section{RADIATION EXPOSURE}

Livermore, Calif., Jan. 6, 1959 -Ref: -HS-59-103

\section{Nature of Accident}

Physicist was exposed to radiation from an electron accelerator. 


\section{Description of operation}

A new electron linear accelerator was being operated to accumulate data to enable the engineering section to design permanent equipment for this machine. A number of remote operating circuits were not in operation, including remote controls for the tungsten beam definers, remote radiation monitoring system, and the interlocked barrier to the beam room area. The barrier was temporarily replaced by $4 \times 4 \mathrm{ft}$ plywood and a warning sign.

Details of Accident

A series of adjustments were being made on beam defining plates. Radiation surveys were made with negative results when personnel entered the cell after the first three adjustment runs. No survey was made after the fourth and fifth runs. A survey made after the sixth run showed 1,000 r per hour level.

During all entries to the cell, the key which was designed to lock all controls in the "OFF" position was removed from the control panel.

\section{Nature of Inimices or Loss}

It was determined that the film badges had been exposed to about $200 \mathrm{kev}$ energy ganma radiation. An exposure dose of $41 \mathrm{r}$ was assigned to physicist $\mathrm{A}$. This dose was received in a period of about one minute, which was the established time he worked alone on plates 3 and 4 and entered the cell to measure very high radiation levels. The next highest reading of $400 \mathrm{mr}$ was received by physicist $B$. All others received less than $50 \mathrm{mr}$.

\section{Remarks}

Reliance was placed for saie operation on incomplete safety interlock circuits. Extreme care should be exercised in all situations where it is known that mechanical safety may be incomplete or inoperative.

\section{EXPLOSION}

Richland, Wash., Mar. 31, 1959-Ref: - HS-59-7

Nature of Accident

Explosion in glove box spread contamination.

\section{Descriplion of Operation}

Experimental machining of plutonium in glove box.

\section{Details of Accident}

Two employees, $S$ and $D$, were doing experimental machining on pieces of plutonium. Four other employees were nearby. The work site was a glove box machining hood.

While $D$ was machining the last cut, $\mathbb{S}$ was assisting with the customary removal and storage of plutonium turnings in a metal can. The explosion occurred during the third pass. Both $S$ and $D$ saw an orange flame that seemed to start from the floor of the hood and expand in a split second like a ball until it filled the hood.

Houselseeping in the hood was good. The glove bos was clear of turnings and the three $\mathrm{Pu}$ pieces were still in a plastic bag. The only other combustibles were placed away from the machine out of range of any sparks.

In machining the face of a narrow piece, as in this case, the tool strilkes the metal several times a second and makes sparks with nearly every contact. In a normal air atmosphere, the sparking is more pronounced. Common practice in this and similar glove box work is to inert the atmosphere by charging the box with argon. The argon does not displace the air completely, but dilutes it so that the oxygen content is kept low. With some materials, for example, 
when using carbon tetrachloride as a coolant, experience had shown the argon atmosphere to be unnecessary. Thus, the need to use argon came to be a matter of judgment. In this case, the operator did not use the argon.

The coolant used depends on the metal being machined. For this application, trichloroethylene, $\mathrm{HClC}: \mathrm{CCl}_{2}$, was stipulated. Reasons for its use were its relatively low toxicity, its volatility, and its listing as a nonflammable naterial.

On March 30 , the day before the explosion, the operator of the lathe set out to replenish the coolant supply in the lathe's reservoir and obtained a 5-gallon safety can full from the drum of trichloroe thane. The significant factor in this action is the label on the drum from which he drew. It read:

\section{CHLOROTHENE inhibited \\ $1,1,1$-trichloroethane}

The possibility of mistaking a material so labeled for trichloroethylene is obvious.

This substitute solvent was used all day on the 30 th without incident. A half hour before the explosion on the 31st, the operators noticed a little puff of smoke within the hood.

Trichloroethane, as well as trichloroethylene, has no flash point and is listed as nonflammable. After this incident, however, it was demonstrated in a mockup glove box, that explosions can be produced by boiling either solvent in a static atmosphere. The experiment consisted in evaporating about 200 cubic centimeters of solvent from a beaker over an openwire hot plate. Cloudiness in the hood, evidently from thermal decomposition of the vapors, preceded an explosion. With trichlorocthone, 4 to 8 minutes were required to produce the explosion. With trichloroethylene, the explosion required about six times as long. Ignition in the accidental explosion was probably supplied by the sparking plutonium Iragments. (Note: Common thermal decomposition products of these two solvents are $\mathrm{CO}, \mathrm{COCl}_{2}$, and $\mathrm{HCl}$.)

The principal causes of this accident appear to have been: (1) inadequate labeling of solvent containers and lack of control in disbursement of hazardous materials; and (2) failure to establish an inflexible procedure requiring inert atmosphere in plutonium machining operations.

\section{Nalure of Injuries or Loss}

Bio-assay sampling results currently indicate an internal deposition probably less than $20 \%$ of the maximum permissible limit in one individual.

Physical damage was limited to the lucite panels of the hood, costing $\$ 200$, and replacement cost of the alpha monitoring instrument, valued at $\$ 1,449$, which could not be decontaminated.

\section{RADIOACTIVE SOLVENT CONTAMINATED ROADBED}

Ailsen, S. C., Apr. 2, 1959-Ref: - HS-59-8

Nahre of Accident

Contaminated solvent spilled on roadbed.

Description of Operation

Transporting organic solvent containing intermediate level fission products to plant burial ground.

Details of Accident

While contaminated process solvent was being transported to underground storage tanks in the burial ground, a small volume (estimated at less than one gallon) of the solvent leaked 
from the forward hatch of the solvent trailer and dripped onto the roadway. Approximately one-half mile of road was spot contaminated from the railroad crossing to the burial ground. Radiation levels at these spots ranged up to $8,000 \mathrm{c} / \mathrm{m}$.

Investigation of the incident has shown that the contaminated process solvent leaked out of the forward hatch cover of the tank trailer. The retaining wing-nut had been replaced with an ordinary nut which, investigation showed, can slip out of place even though it appears to be properly tightened. Since the rate of radiation exposure to personnel loading the tank trailer was as high as $1,500 \mathrm{mr} / \mathrm{hr}$ and the forward hatch is seldom used, except when cleaning the tank trailer, the hatch was not inspected before the tank trailer left the area. Five loads of this solvent had already been transported to the burial ground without incident.

Nature of Injuries or Loss

The solvent dissolved into the asphalt of the roadway quickly upon contact. The cost of cleanup was $\$ 8,700$.

\section{CURIUM 244 CONTAMINATION}

Berkeley, Calif., July 3, 1959-Ref: - HS-59-18

Nature of Accident

Overpressurization of a box for helium cooling blew out and caused disintegration of thin experimental foil containing $10^{11}$ DPM of Curium 244.

Description of operation

Bombardment of curium targets by degraded heavy ion beam.

Details of Alcident

An experimental setup included two curium targets in a helium atmosphere for intended bombardment by degraded heavy ion beam. Each target contained approximately 150 micrograms of curium (95\% Curium 244; $5 \%$ heavier isotopes) electroplated on a 0.0001 inch nickel foil spot-welded across a $1 / 4$-in. diameter hole in a stainless steel plate. The target chamber was separated from the vacuum by the degrading-foil assembly consisting of variable aluminum absorbers mounted in a circulating helium cooling atmosphere. Windows of 0.0001 inch nickel foil across $3 / 8$-in. diameter holes were used to allow passage of the beam through this unit.

Prior to performing the experiment, it was necessary to remove air by llushing the degrading-foil chamber with helium which was then bled out to the cave. After this purge operation had been conpleted - a matter of 10-15 minutes - the experimenter closed the helium bleed valve to the cave but forgot to open the return valve on the system to complete the gas circuit for the circulation pump. He then turned on the helium circulating pump which caused helium pressure increase to approximately 9 psi, at which point the window exploded. The curium target material "literally exploded," blowing curium dust into the cave. Natural draft carried much of the activity over the cave shielding wall into the main accelerator room. Natural air currents and ventilating blowers further distributed contamination throughout the building. The experimenter, upon hearing a sound, entered the cave to investigate and noticed the broken window on the target side. An alpha meter check showed $10^{5}$ counts per minute on the target side of the absorber changer and upwards of $10^{4}$ counts per minute on the floor, table, apparatus, and himself.

Nature of lnjuries or Loss

The cost of labor, material, and other charges relating to this "spill" amounted to about $\$ 30,500$ without overhead; equipment loss was held to less than $\$ 2,000$. The loss time of the 
operation of the high energy linear accelerator has been estimated at $\$ 26,000$. Total loss from the incident approximated $\$ 58,500$.

\section{FIRE IN FILTERING SYSTEM}

Los Alamos, N. Mex., July 15, 1959-Ref: - HS-59-194

Noture of Accident

A fire occurred in a unit air filter.

Description of Operation

Installation of a new ventilation and filtering system.

Details of Accident

A unit filtering system on the east side of the room was in process of revision when the "asbestos" filter caught fire from sparks or hot metal from a welding torch.

This filter was the old type CWS filter, consisting of a plywood frame, $24 \times 24 \times 12$ in., filled with felted asbestos paper between cardboard spacers. The spacers were coated with sodium silicate fire retardant. This filter had been in use for about $4 \frac{1}{2}$ to 5 years and was heavily loaded with dust from the plutonium metal production lines in that room. As a result of the fire, the room was heavily alpha contaminated. Some surrounding ground was contaminated to a level of about $20,000 \mathrm{~d} / \mathrm{m}$.

Since the operation being performed, that of changing the ventilation system, was a contaminated operation, the workers in the room were wearing respiratory protection and protective clothing at the time of the fire.

Combustion seems to have involved the plutonium compounds caught in the filter, for it is difficult to understand how such temperatures could have evolved from the relatively small amount of combustible material in the filter itself. The stainless steel filter holder and a length of duct remained red hot for several minutes after the filter burned.

Nature of Injuries or Loss

Since the old filter was scheduled for disposal, no property damage resulted from the fire. The cost of decontamination of the room involved and its surrounding grounds was $\$ 1,000$ to $\$ 1,500$.

\section{RADIOACTIVE RELEASE TO ATMOSPHERE}

Los Alamos, N. Mex., July 17, 1959-Ref: -HS-59-19

Nature of Accident

Release of radioactive gas to atmosphere.

Description of operation

Changing a low pressure gas system to high pressure.

Details of Accident

Prior to an experiment, a low pressure gas line containing radioactive gas was being pumped out preparatory to transferring the gas to a high pressure system. During this operation, radioactive gas was released to the atmosphere through a valve on the low pressure line, 
which was either inadvertently left open or the switch controlling the valve was accidentally knocked open.

Nature of Injuries or Loss

Personnel exposure was insignificant.

Loss of radioactive gas amounted to $\$ 10,300$.

\section{DRY BOX EXPLOSION}

Miamisburg, Ohio, Aug. 6, 1959-Ref: - HS-59-24

Nature of Accident

Spontaneous explosion in a dry box.

Description of Operation

Process and electrolysis dry box line.

\section{Details of Accident}

A laboratory technician filtered 800 milliliters of a solution presumed to be contaminated wash water in a polyethylene beaker standing in a hood. The solution then was transferred by vacuum into a temporary storage bottle in another hood. He also transferred into this storage bottle a solution of nitric acid in which some nickel containers for polonium had been dissolved and which had been left standing until reaction had been completed. The bottle was vented and was being allowed to stand until the next day. Upon investigation, it was found that the polyethylene beaker contained acetone wash from the previous day. When no sink was available, it was the custon to place this wash into the storage bottle until proper disposition could be made. This combination of acetone wash (unknown at time by the laboratory technician) and nitric acid solution produced the chemical explosion. This explosion shattered the storage bottle (four-liter) and glass apparatus in the hood; broke the viewing window in the hood; split the door and tore of the latch on the back of the hood; ruptured the gauntlets and spread the 39 curies of polonium into the room and corridor.

Nature of Injuries or Loss

No personal injuries resulted as no one was present at the time of the explosion.

Some equipment was contaminated. Total cost $\$ 1,900$.

\section{CONTAMINATION ACCIDENT}

Aiken, S. C., Aug. 21, 1959-Ref: - HS-59-27

Nature of the Accident

A crane in a chemical separations plant was contaminated with high level radioactive solution.

\section{Descriplion of the Operation}

Chemical separations equipment housed in shielded "canyons" is operated remotely by use of an overhead crane and other devices.

\section{Details of Accident}

In an attempt to locate and correct pluggage, three hot canyon cell covers were removed with a crane and the remote disconnect type flanges loosened on the discharge connection from 
a thermally hot, high activity waste evaporator. Solution leaking from the loosened flange vaporized as it hit the hot evaporator. Thermal currents carried highly radioactive vapors from the cell, grossly contaminating the crane. Radiation readings as high as $50 \mathrm{r}$ at four feet at one point made direct maintenance to the crane impracticable. Concurrently with the events described above, continuous monitors detected existence of slightly above permissible tolerance levels of airborne radioactivity in certain sections of the building occupied by employees. For a brief period, masks were required for use by all personnel, except those in one section of the building.

\section{Nature of Injuries or Loss}

With the crane out of service, it was necessary to terminate temporarily hot cell operations until decontamination could be effected by hydrocleaning methods. There was production down time during cleaning operations. There were no exposures to radiation above allowable limits.

There was no property damage beyond the loss of use. Cleaning operations costs were approximately $\$ 129,000$.

\section{Remarks}

The incident outlined above led to a number of studies aimed at minimizing future risk of similar occurrences. These include provision of evaporator cooling facilities (which had not been provided in initial design), modification of cell operating procedure to require cooling and spray-down with water before removing cell covers, provision of a second crane, and studies to increase differential ventilating air pressures between the canyon cells and the canyon area.

\section{CRITICALITY INCIDENT}

Idaho Falls, Idaho, Oct. 16, 1959-Ref: - HS-59-33

\section{Nature of Accident}

A nuclear incident occurred in a process equipment waste collection tank at one of the AEC chemical processing plants.

\section{Description of operation}

This facility is used for processing stainless steel-clad highly enriched uranium fuels.

\section{Details of Accident}

The incident resulted from the accidental transfer of about 200 liters of urdnvl nitrate solution containing about 34 kilograms of enriched uranium (91 per cent U-235) from critically safe process storage tanks to a geometrically unsafe tank through a line normally used for waste transfers.

Although no specific instances of maloperation were found, the lack of critical analysis of the operating equipment for possible sources of trouble (e.g., air lines without flow restricting orifices, valving of lines from critically safe to critically unsafe vessels, and pressure gauge installation unknown to operators using the equipment) and the lack of careful attention to initial operations in seldom-used equipment appears to represent significant errors of omission in a plant as complex as this one.

Nature of Injuries or Loss

Limited visual inspections and tests indicated that no significant property damage or loss resulted beyond the approximately $\$ 60,000$ cost to recover contaminated uranium solution resulting from the incident. 
Of the 21 personnel directly involved in this incident, 7 received external exposure to radiation worth mention. Of the 7, none received a year's maximum permissible "whole body" exposure of penetrating radiation. Two exceeded the year's maximum permissible exposure to the skin. As reported, these individual external exposures were $50 \mathrm{rem}$ and $32 \mathrm{rem}$. No medical treatment was required for the 21 personnel involved.

\section{STACK RELEASE}

Oak Ridge, Tenn., Nov. 11, 1959-Ref: - HS-59-259

Nature of Accident

Particles of radioactive elements were accidentally released from a stack.

Description of Operation

Plant operation.

Details of Accident

A small amount of ruthenium 106 and rhodium 106 was released from a stack and settled to the ground in the immediate vicinity. The release is believed to have resulted from repair of a fan used with the stack. Materials apparently accumulated during the operation of a less powerful fan and were discharged when the repaired fan was restarted.

Nature of Inimies or Loss

The release represented no hazard to the public or to the employees.

\section{EXPLOSION RELEASES PLUTONIUM}

Oak Ridge, Tenn., Nov. 20, 1959 -Ref: - HS-59-37

Nature of Accident

An explosion in a processing vessel during a cleanout and decontamination procedure caused extensive contamination.

Description of Operation

Cleanout and decontamination of a processing vessel in a radiochemical pilot plant.

Details of Accident

The pilot plant was on shutdown status at the time of the accident, except for the decontamination operations in progress.

Two days prior to the accident, a decontaminating agent was added directly to the evaporator section and heated. This was followed by a water wash and then a $30 \% \mathrm{HNO}_{3}$ treat ment. The desired results were not obtained and more drastic efforts were made.

Events leading up to the accident are reported as follows: 200 liters of the decontaminant were added to the condensate tank and jetted to the steam stripper, which drains into the evaporator. After boiling for two hours (in the evaporator), the decontaminant was run out through the remotely operated normal drain, which was somewhat above the lowest point of the system, leaving an approximate 15 liter "heel." This could only be drained through a handoperated valve on the extreme bottom of the system. High radiation levels in the cell would not permit entry by personnel. 
Two hundred seventy liters of $20 \% \mathrm{HNO}_{3}$ were then added directly to the evaporator (skipping the water wash and neutralizer recommended by the manufacturer), combining with the remaining decontaminant, and boiled for about two hours, concentrating the $\mathrm{HNO}_{3}$. The remotely -operated evaporator drain valve was opened, and while draining, the explosion occurred.

\section{Nature of Injuries or Loss}

A small residue of plutonium was blown out, contaminating nearby buildings, several vehicles, roadways, and grounds in an area of approximately four acres. No one was injured by the blast. The immediate area was evacuated and steps were taken to avoid excessive exposure of persons entering the contaminated area to radioactivity.

As later determined, damage to processing equipment as a direct result of the explosion amounted to $\$ 10,000.00$ and decontamination costs are estimated at approximately $\$ 350,000.00$.

\section{POLONIUM 210 EXPOSURE}

Miamisburg, Ohio, Nov. 30, 1959-Ref: - HS-59-272

Nature of Accident

Two employees received internal body burdens of polonium 210 , approximately twice the maximum continuous body burden permissible at this laboratory.

Description of Operation

Maintenance work in polonium area at a laboratory.

Letails of Aceident

On November 30,1959 , two sheet metal workers were assigned the job of changing supply and exhaust lines on a group of highly contaminated closed hoods. The job was difficult and took considerable time to complete.

\section{Nulure of Injuries or Loss}

The result of a 24-hour urine specimen submitted by one employee on December 21, 1959 , indicated that his body burden on that day was approximately 1.37 times the maximum permissible continuous body burden. Based on a 36-day effective half-life, his initial body burden on November 30,1959 , would have been approximately 2.05 times the permissible.

The result of the other employee indicated 1.99 times at time urine specimen was taken, which would be approximately 3.90 times the permissible at time of incident.

\section{RUPTURED LINE SPRAYS CONTAMINATION}

Idaho Falls, Idaho, Nov. 30, 1959-Ref: - HS-59-267

Nature of Accident

Failure of equipment.

Description of Operation

Reactor. 
Rupture in a reactor core section of an inpile tube caused spread of highly contaminated liquid (approximately $25 \mathrm{rep} / \mathrm{hr}$ at $1 \mathrm{ft}$ ).

Nature of Iniuries or Loss

Cleanup of decontaminated area and replacement of damaged instruments caused by the spraying liquid cost $\$ 4,720$.

\section{ON-SITE RAILROAD AND GROUNDS CONTAMINATION}

Aiken, S. C., Dec. 12, $1959-$ Ref: - HS -59-40

Nature of Accident

Contamination of equipment, on-site railload and grounds from burial box.

Description of Accident

On Saturday, December 12,1959 , at approximately 11:00 p.m., during railroad transportation of a burial box containing canyon pipe jumpers, radioactive particulate matter was shaken loose from the box, resulting in the spread of contamination along the railroad right-of-way. The diesel locomotive and several spacer cars were also contaminated.

Investigation of the incident has shown that the lid of the box which was stored in the canyon probably became contaminated due to the numerous crane movements over it while loading the jumpers into the box, and later this material (radioactive particulate matter) was scattered by the wind during movement of the train.

Nature of Injuries or Loss

Cost of removal of the contaminated soll and decontamination of the diesel locomotive and railroad cars was $\$ 5,200$.

Remarks

Procedures for handling burial boxes have been reviewed with special consideration being given to (1) storage of the burial box lid in a location to minimize external contamination, (2) establishing a method for obtaining more detailed Health Physics surveys on all high level shipments and (3) scheduling the removal and burial of equipment so that there will be a minimum of movement of the loaded burial box.

\section{PLUTONIUM INCIDENT}

Los Alamos, N. Mex., Jan. 15, 1960-Ref: - HS-60-2

Nature of Accident

A glass bottle containing a plutonium solution ruptured in laboratory.

Description of Operation

Thermal decomposition studies of plutonium trichloroacetate.

\section{Details of Accident}

Plutonium trichloroacetate had been prepared for thermal decomposition studies, the material had been heated in air to $800^{\circ} \mathrm{C}$, and showed no instability. After the research work was completed, the acetate was ground up, and dissolved in about $500 \mathrm{cc}$ of $4-5$ molar nitric acid. The solution was filtered, and the filtrate was allowed to stand in an open container in a glove 
box for about three weeks. On the morning of January 15,1960 , the filtrate was transferred to a ground glass stoppered bottle, sealed in a plastic bag, removed from the glove box, placed in a stainless steel transfer can, and placed on a shelf. A short time thereafter, the bottle erupted, contaminating the walls and ceiling of the room.

Nature of Imjuries or Loss

Three men were present at the time of the incident. Twenty-four-hour urine sample evaluations are as follows: $2.3 ; 2.0$; and 6.8 disintegrations per minute.

The cost of decontamination of the laboratory was $\$ 4,000$.

\section{FIRE RESULTED IN SPREAD OF RADIOACTIVE PARTICLES}

Richland, Wash., Feb. 25, 1960-Rei: - HS-60-6

Noture of Accident

A small fire resulted in spread of radioactive material in a limited area.

Description of operation

The incident occurred during installation of equipment in one portion of the building.

Details of Accident

The fire occurred during the welding of a two-inch diameter pipe duct into the top of the ion exchange hood in a cell. At the start of the welding operation, a spark dropped into the hood and two small fires occurred, which in turn ignited an $8 \times 8 \times 6 \mathrm{in}$. CWS nonfire-resistant inlet filter. Openings in the hood, caused by the fire and attempts to extinguish it, allowed contamination to be spread to adjacent rooms and the corridor.

Nature of Injuries or Loss

Six workers in the vicinity were exposed to external contamination. All six were wearing respiratory protection and protective clothing. After routine decontamination procedures, all of the men were released to return to their homes shortly aiter their shifts were completed.

Equipment losses and decontamination costs were $\$ 4,250$.

\section{RADIATION EXPOSURE}

Oak Ridge, Tenn., Mar. 8, 1960-Ref: - HS-60-8

Nature of Accident

An employee received a radiation exposure to the skin above the level established for routine occupational activities.

Description of Opezation

Scheduled cleanup of a cell used for handling radioactive materials.

Details of Accident

The employee was exposed while performing routine cleanup in the cell under a time limit designed to limit his exposure. The time limit was based on the radiation levels previously measured in the cell. Contrary to established procedure, the employee did not wear a face mask but did wear the customary protective clothing. 
The employee received a beta dose (relatively nonpenetrating) estimated at up to 5500 rads to the dead outer surface of the skin. The dose was about 2,000 rads at 2 millimeters below the slkin surface, the depth at which skin reactions occurred.

He developed erythema (redness of the skin) on his fingers and hand.

\section{NOZZLE LEAK}

Aiken, S. C., April 5, 1960-Ref: - HS-60-16

Nature of Accident

A leak in an outlet nozzle on a reactor.

Description of Operation

Reactor operation.

Details of Accident

The reactor was shut down to locate the source of $\mathrm{D}_{2} \mathrm{O}$ leakage around a reactor outlet line. The elevation of the leak was determined by hydraulic tests, and excavation through the concrete biological shield revealed that the leak point was a crack in one of the suction nozzles.

Nature of Tnjuries or Loss

The foiled section of the nozzle was removed and repair was effected. Cost $\$ 216,285$ for repairs and heavy water loss.

\section{PLUTONIUM POWDER SPILL}

Los Alamos, N. Mex., April 13, 1960-Ref: - HS-60-145

Nalure of Accident

A spill of plutonium powder occurred during an experiment.

Description of Operation

Hot laboratory.

\section{Details of Accident}

A spill of plutonium powder occurred during an experiment. The building where the spill occurred was designed for "hot" operations. The building consists of three rooms: a hot lab, a change room with shower and washroom facilities, and a cold lab for instrumentation and control purposes. These three rooms are directly connected by doorways with the change room in the middle. The building is equipped with a ventilation system which is intended to provide a pressure differential between the hot side and cold side.

The spill occurred as a result of the failure of an experimental device used to inject plutonium powder into a receiver.

To operate the system, a valve between the He reservoir and the $P u$ powder is opened by hand. The He gas is then remotely released from the reservoir. As the He flows through the Pu powder cell, the Pu powder is ejected and carried by the gas flow into the receiver. A 
needle valve, located between the receiver and filter, is slowly opened by hand, allowing the gas to exhaust from the system. The $\mathrm{Pu}$ is retained by the filter and may be recovered.

The He reservoir, Pu powder cell, and receiver had been tested with pressures of $10,000 \mathrm{psi}, 7,000 \mathrm{psi}_{\text {, }}$ and $750 \mathrm{psi}$, respectively. The pressure of the system after the gas has stabilized is approximately 170 psi. The joint which failed was a silver-soldered joint on the exhaust side of the Pu powder cell. This joint had not been pressure-tested but the system had been operated three times, using inert powders, without showing signs of leakage. For the operation in which the spill occurred, the powder cell was loaded with $1.5 \mathrm{gm}$. of Pu-239 oxide, of about 1 micron particle size.

At the time of the experiment, there were six people in the cold room. Three constituted a monitoring team and were dressed in protective clothing. About a minute or two after the first valve was opened, the monitoring team left the cold room and two of them entered the hot room to check the device for leaks. On opening the door to the hot room, a high count was evident. The pressure gauge on the receiver read zero, indicating that a leak had occurred. They immediately closed the door, returned to the cold room and had the other people leave.

All of the monitoring meters were contaminated so the Rad-Safe Group was called for assistance and uncontaminated meters.

Subsequent examination of the experimental system showed that all high pressure fittings were tight. Discoloration of the high pressure tubing on the exhaust side of the Pu powder cell indicated that a leak had occurred in this silver-soldered joint.

\title{
Nature of Injuries or Loss
}

It is estimated that $300 \mathrm{mg}$. of plutonium powder was released into the room. Two of the personnel who entered the room received no plutonium in the body and the other received a trace amount. Estimated decontamination costs are $\$ 2500$.

\section{DISSOLVER ACCIDENT}

Richland, Wash., Apr. 17, 1960-Ref: - HS-60-14

\section{Nature of Accident}

Fire and explosion in a dissolver with contamination spread.

\section{Descriplion of Operation}

Extracting and refining of special materials from irradiated fuel materials.

\section{Details of Accident}

Fire and explosion in pyrophoric metal contents of a chemical dissolver caused high damage to dissolver, off-gas filter, and related process equipment. Contamination spread to cell, canyon, and crane. The cause or causes of the accident are not established.

Nature of Injuries or Loss

There were no injuries and no radiation exposures to personnel. Approzimate government loss, $\$ 250,000$.

\section{PERSONAL CONTAMINATION INCIDENT}

\author{
Richland, Wash., Apr. 26, 1960-Ref: - HS-60-17 \\ Nature of Accident
}

An employee was pierced by a splinter of metallic plutonium through the rubber glove he was wearing. 
Arranging equipment in a hood.

Details of Accident

An employee was positioning a graphite funnel, preparatory to making a casting of plutonium. The employee felt a slight pricking sensation in his right forefinger while positioning the graphite funnel. The work was being accomplished in an enclosed glove box utilizing 30 mil neoprene gloves. When the employee withdrew his hands from the glove box gloves, a check with a radiation detection instrument showed his surgical glove on his right hand contaminated to greater than $80,000 \mathrm{~d} / \mathrm{m}$.

\section{Nature of Tnjuries or Loss}

After the removal of the splinter, the employee was taken to whole body counter facilities where a count indicated $90,000 \mathrm{~d} / \mathrm{m}$ still remaining in the wound. The physician excised a section of tissue and a follow-up count indicated $600 \mathrm{~d} / \mathrm{m}$ remaining in the wound. A urine sample was then collected, the first void since the incident, and the patient was released to go home with instructions to collect and save urine specimens that night. He returned to work April 27.

\section{SOLID STATE INCIDENT}

Oals Ridge, Tenn., Apr. 26, 1960-Ref: - HS-60-15

Nature' of Accident

A change in the internal air flow in the building carried radioactive material out of a cell in which an irradiated fuel element was being examined.

\section{Description of operation}

A graphite impregnated fuel element had been irradiated and was being cut in two.

\section{Details of Accident}

An irradiated, graphite-clad reactor fuel element was being cut inside the cell with a remotely-operated saw. A change in air pressure inside the cell forced contaminated graphite dust from the cell. This change in pressure apparently was caused by the top slab having been removed from an adjacent cell and by wind blowing through an open outside door immediately behind the cell. These conditions caused the pressure inside the cell to become positive to the extent that it forced graphite particles contaminated with cerium and strontium into the work areas immediately in front of the cell.

\section{Nalure of Injuries or Loss}

In addition to the eight persons in front of the cell, 72 others were in the building at the time of the incident. All were evacuated from the building. As a precaution, bio-assay samples were taken from all of these and analyses have been completed for 25 most likely to have been exposed. Of these, only two showed any evidence of internal exposure and neither was in excess of the $0.1 \mathrm{rem}$.

Cleanup of the area $\$ 39,500$.

\section{FUEL ELEMENT SHIPMENT ACCIDENT}

Baltimore, Md., June 2-6, 1960-Ref: - HS-60-28

Nature of Accident

Dribbling of water running out of the overflow pipes at each end of the cask water expansion tank on top of a 55-T shipping cask. 
Shipment of 99 NRU fuel elements.

\section{Details of Accident}

AEC shipment couriers, escorting a 55-T fuel element shipping cask containing 99 NRU fuel elements en route to South Carolina for reprocessing, noticed a dribbling of water running out of the overflow pipes at each end of the cask water expansion tank on top of the shipping cask. The lowboy flat bed freight car was being moved in regular fast freight when the leakage began about 40 miles north of Baltimore, Maryland. Due to the alertness of AEC couriers, they observed the leakage when it began and noted the approximate point on the railroad route. They were also able to observe that there was very little of the water that did not puddle on the top of the cask or on the bed of the freight car. At the earliest possible opportunity, the couriers monitored the overflow with their survey meter and found that the water was contaminated with radioactivity greater than the level of 10,000 counts per minute.

Nature of Injuries or Loss $\$ 24,000$.

Thirty to fourty gallons of contaminated water leaked from the cask. Cleanup costs,

\section{DRYBOX CONTAMINATION ACCIDENT}

Miamisburg, Ohio, July 6, 1960-Ref: - HS-60-24

\section{Nature of Accident}

Accidental discharge of radioactive material into a room as a result of pressure buildup in a drybox.

\section{Description of Operation}

The purging operation of the inert atmosphere drybox.

\section{Details of Accident}

A cylinder of argon used in purging of equipment ran low on pressure causing various solenoids to malfunction. When new cylinder of argon was installed, the valves admitted too much pressure, causing gloves to blow off of glove ports and spreading radioactivity into area.

Nature of Injuries or Loss

As a result of the accident, eleven individuals received minor exposure to radioactive particles in the atmosphere. Radioactive material was also deposited on clothing, hair, hands, etc. The material was removed by substitution of clean clothing and appropriate cleansing of skin and hair. Cost $\$ 31,360$.

\section{CONTAMINATED COOLING WATER}

Aiken, S. C., Sept. 13, 1960-Ref: - HS-60-26

\section{Nature of Accident}

Contaminated cooling water was discharged from canyon onto floor. 
Separations facility.

De'ails of Accidem

Contaminated spent cooling water from the calandria of a continuous type high activity waste concentrator in a building was inadvertently discharged to the floor of the hot gang valve corridor. This overfilled the floor drainage collection system, resulting in a flow of contaminated water throughoul the corridor and down a stairwell to the first level personnel corridor, where it flowed into two locker rooms, an office and counting room, and the personnel decontamination room. The affected floor areas were contaminated in varying amounts, ranging from $10 \mathrm{rad} / \mathrm{hr}$ to $200 \mathrm{rad} / \mathrm{hr}$. It was necessary to suspend processing operations, pending a reduction in radiation in the corridor, and to vacate the affected first level corridor and rooms until cleanup efforts made the areas habitable.

Nature of lnjuries or Loss

No overexposures. Cost $\$ 250,000$.

\section{RADIATION EXPOSURE}

Mercury, Nev., Oct. 4, 1960-Ref: - HS-60-41

Nature of Acciden

Two employees were accidentally exposed to ionizing radiation coming from a 340 curie $\mathrm{Co}^{60}$ calibration source.

Description of Operation

Calibrating scintillation detectors.

Details of Accident

Two employees were following through the routine involved in the calibration of photocell detectors. The detectors were placed in the radiation beam area, 30 inches in front of the cobalt source unit. Currents were being recorded for each detector with the rotor-shutter open. Three detectors had previously been calibrated; the fourth was placed in position; both personnel returned to the console; the shutter and rotor were opened, and the current output of the detector was recorded. After recording the current value, employee " $A$ " noted the shutter and rotor lights (located on the console) to be out and assumed the shutter and rotor to be closed. He approached the detector located in front of the source (without taking the safeguard radiation instrument), and started making mechanical adjustments on the photodiode. Employee " $B$ " followed " $A$ " and aided him in the adjustments.

Nature of Injuries or Loss

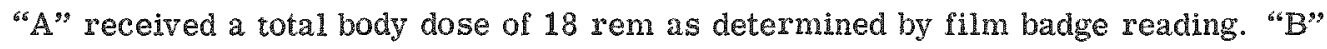
received a total dose of 5 rem.

\section{RADIATION EXPOSURE}

Albuquerque, N. Mex., Nov. 11, 1960-Ref: - HS-60-31

Nature of Accident

An employee, "A.", was accidentally exposed to an electron beam emanating from a Van de Graaff accelerator. 


\section{Description of Operation}

Setting up an experiment in front of the beam tube of Van de Graaff accelerator.

\section{Details of Accident}

The machine operator, employee " $B$ ", put the machine on self-charge with ${ }^{6} \mathrm{~A}$ ' $s$ " consent and knowledge, as "A" entered the beam room. This was done to check the self-charge rate and limit of the machine. The term "self-charge" refers to the operation of the belt which places a static charge on the high voltage terminal. The beam current and belt charge (the normal source of electrons) were not turned on. Therefore, there should have been no detectable emission from the beam tube at this time.

"A" proceeded to end of the beam tube and began setting up his experiment. After approximately two minutes, he came out of the beam room, since his face felt warm. He then went to the washroom and washed his face. " $A$ " asked " $B$ " if there was any residual beam current. The operator stated that the beam current was not on, but that he would check. "B" entered the beam room with a low range survey meter and made a measurement in front of the beam tube. At first he saw no reading, but as he started to leave, the meter pegged at 20 millirems.

\section{Nature of Injmies or Loss}

"A" received multiple radiation burns in the middle section of the face, abdomen, and both hands. Employee was not wearing his film badge. However, an indirect measurement was made by placing a film badge at the $33 \mathrm{~cm}$ distance and exposing it under simulated conditions. Calibration was interpreted as 760 rads incident dose to the lace at $33 \mathrm{~cm}$.

"B" received a total body dose of 53 rads as determined by film badge reading.

\section{ACCIDENTS INVOLVING FATALITIES IN ATOMIC ENERGY ACTIVITIES 1959 - 1960}

Since the beginning of the atomic energy program in 1943 , a total of 6,562 lost time injuries have occurred in AEC plants and installations through 1960. Of these, 35 were injuries due to overexposure to radiation (see Table 4). This table, which previously appeared in TID 5360 , Supplement 2 , has been revised and updated. Total deaths during the period were 219 , of which three were due to radiation exposure (see Table 5 and Chart 2).

The following descriptions add details to fatal accidents already listed in Table 1.

\section{EXPLOSIVES DETONATED}

Los Alamos, N. Mex., Feb. 24, $1959-$ Ref: - HS -59-5

Nature of Accident

Explosion.

\section{Details of Accident}

A detonation of a $7 \frac{1}{2}$-pound cylindrical block of high explosives instantly killed two employees. The accident occurred during a normal machining operation of chemical explosives used to study the physical phenomena of shock waves.

Nature of Injuries or Loss

Two men were fatally injured. 
Table 4 - REPORTED RADIATION ACCIDENTS RESULTING IN LOST TIME INJURIES

(As defined in American Standards Association Methods for reporting work injuries-ASA 216-1-1954 and AEC Manual Chapter 0502)

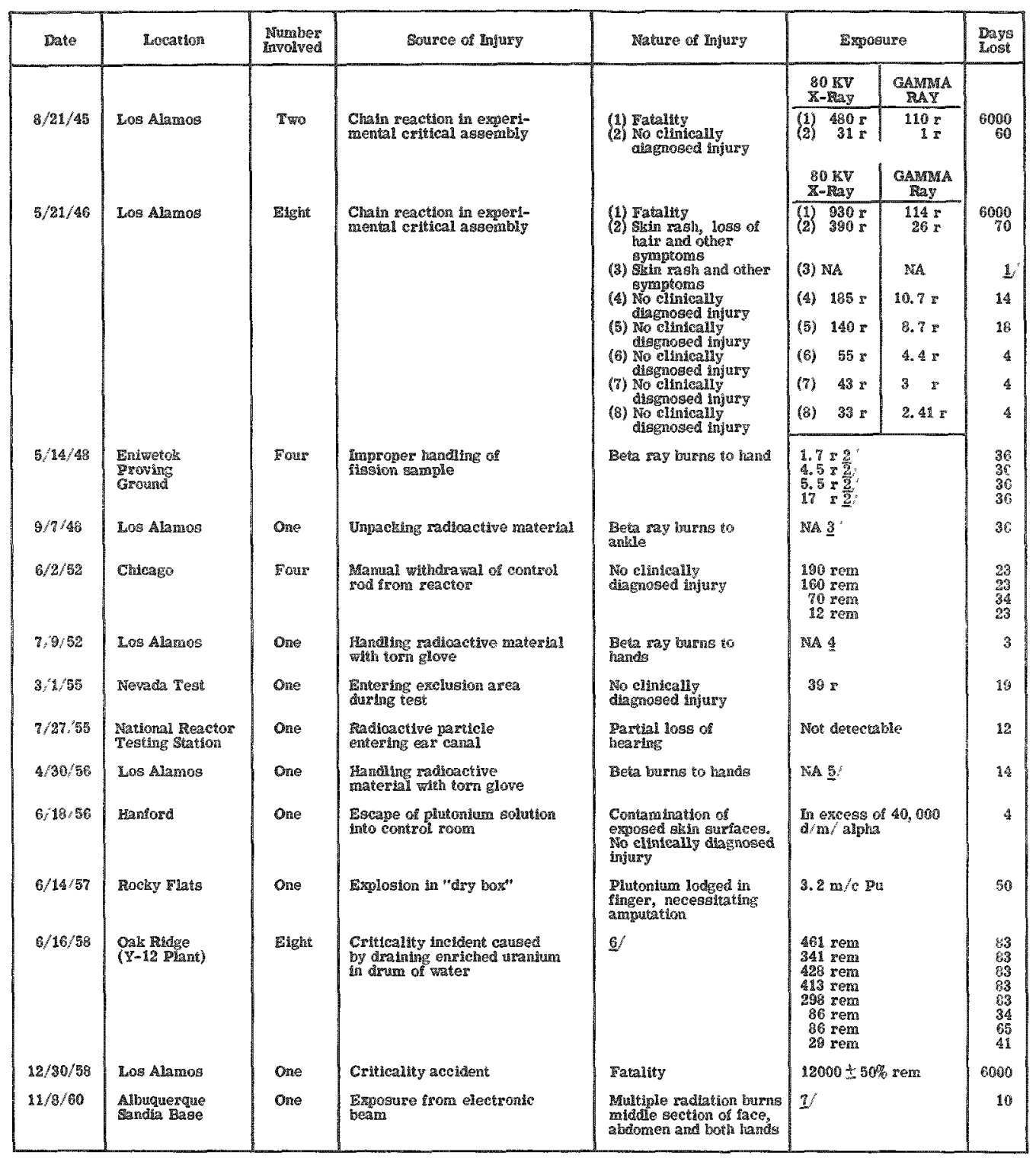

1. Employee had recelved termination notice prior to accident.

2 Expogure refers to whole body gamma radiation. Injury cauged by beta ray doge, amount of which exposure not avaliable.

3 Amoun of beta ray dose not avallable. Total gama ray exnosure during week in whteh acetdent occured was 0.27 ren.

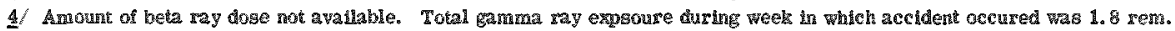

5. Amount of beta ray dose not avalable. Total gamma ray exposure during week in which aceident occured was 2.0 ren.

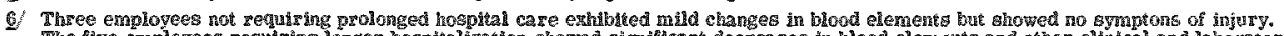

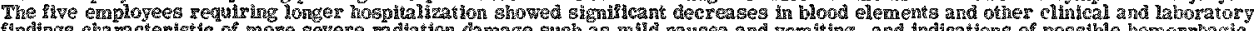

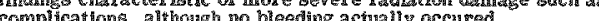

I: Employee was not wearing his fum badge. However an undirect measurenent was made by placing a film badge at the 33 cm distance and exposing it under simulated conditions. Calibration was interpreted as 760 rads incident dose to the face at $33 \mathrm{~cm}$.

NOTES: As exposure previously reported on 10/4/57, Oak Ridge (OFRL) held not lost-time.

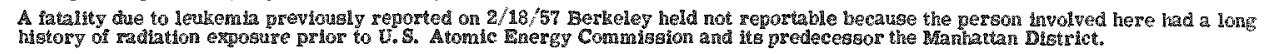


Table 5-FATAL INJURIES MED-AEC

\begin{tabular}{|c|c|c|c|c|c|c|c|c|c|c|c|c|c|c|c|c|c|c|c|c|c|c|c|c|c|c|c|c|}
\hline \multirow[b]{3}{*}{ YEAR } & \multicolumn{3}{|c|}{$\begin{array}{l}\text { OCCUPATHONAL } \\
\text { WATALITIES }\end{array}$} & \multicolumn{11}{|c|}{ CONSTRUCTLON } & \multicolumn{9}{|c|}{ ORERATYONS } & \multicolumn{5}{|c|}{ COVERMMENT } \\
\hline & \multicolumn{2}{|c|}{ MAED-AEC } & \multirow{2}{*}{\begin{tabular}{c} 
NSSC \\
\\
\multirow{2}{*}{}
\end{tabular}} & \multirow{2}{*}{\multicolumn{2}{|c|}{ 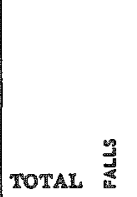 }} & \multirow[b]{2}{*}{ 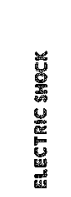 } & \multirow[b]{2}{*}{ 㩊 } & \multirow{2}{*}{ 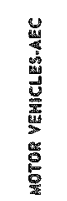 } & \multirow{2}{*}{ 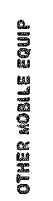 } & \multirow{2}{*}{ 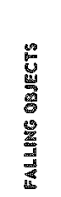 } & \multirow{2}{*}{ 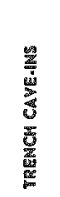 } & \multirow{2}{*}{\multicolumn{2}{|c|}{ 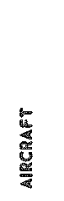 }} & & & & & & & & & & & & 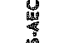 & & & \\
\hline & & 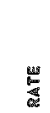 & & & & & & & & & & & & 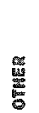 & TOTAI & & 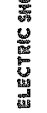 & 蓄 & 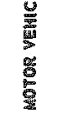 & 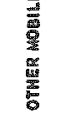 & 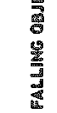 & 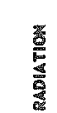 & 逕 & & 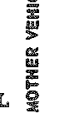 & 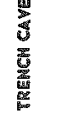 & 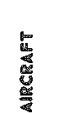 & 递 \\
\hline 1843 & 19 & 37 & 33 & 19 & 5 & 2 & 1 & 3 & 6 & 1 & 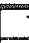 & & & & 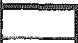 & 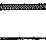 & 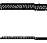 & $\square$ & $\square$ & 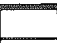 & 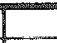 & 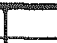 & - & 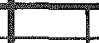 & & & & \\
\hline & & & & & & & & & & & & & & & & & & & & & & & & & & & & \\
\hline 1944 & 34 & 22 & 31 & 29 & 8 & 3 & 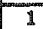 & 2 & 4 & 7 & & & & & 5 & & 3 & & 1 & & & - & 1 & & & & & \\
\hline 1896,1024 & 93 & & & 48 & 14 & 3 & 2 & 5 & 10 & 8 & I & & & & & & & & 1 & & & & & & & & & \\
\hline 1945 & 19 & 16 & 32 & 9 & 1 & 3 & & 1 & 2 & 2 & & & & & 8 & $I$ & 5 & 1 & & & & 1 & 1 & 1 & & 1 & & \\
\hline 10442:1985 & 72 & & & 37 & 15 &. & 2 & 6 & 12 & 10 & 1 & & & & Ti6 & 1 & 8 & 1 & , & & & - & & & & 3 & & \\
\hline 1946 & 8 & 15 & 31 & 1 & 1 & & & & & & & & & & 4 & & & 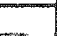 & 1 & 1 & 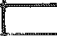 & 1 & 1 & 4 & 2 & & 1 & 1 \\
\hline$\frac{1083-1966}{1047}$ & $\frac{31}{4}$ & 9 & 30 & $\frac{s 8}{1}$ & 16 & - & $\frac{2}{1}$ & - & 12 & 10 & 1 & & & & $\frac{-18}{3}$ & 1 & $\frac{8}{2}$ & 3 & 2 & 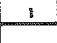 & - & 2 & $\frac{3}{1}$ & 5 & 2 & 1 & 1 & 1 \\
\hline $19862=967$ & 25 & & & 58 & 16 & - & 3 & ${ }_{B}$ & 12 & 10 & 1 & & & & 21 & & 10 & 1 & 2 & 1 & & $2-$ & & $-g$ & 2 & 1 & 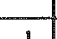 & 1 \\
\hline 1948 & 11 & 17 & 29 & 6 & & 1 & & & $\frac{\pi}{2}$ & & 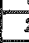 & & & 1 & 4 & & $\frac{1}{1}$ & & 2 & & & & 1 & 1 & 1 & & & \\
\hline $10933-19643$ & 80 & & & 65 & 10 & 9 & {[} & 6 & 7 & 10 & 3 & & & 1 & 23 & 1 & 11 & 1 & -4 & 1 & - & 2 & 5 & 6 & 3 & 1 & 1 & 1 \\
\hline 1948 & 6 & 10 & 26 & 4 & 2 & & & 1 & & 1 & & & & & 2 & & & 1 & & 1 & 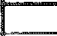 & & & & & & & \\
\hline 1964-31969 & 102 & & & 59 & 18 & $\because$ & 3 & 7 & $\sqrt{14}$ & 11 & 3 & & & 1 & 27 & 8 & n & 2 & 4 & 2 & 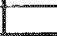 & 2 & 5 & 6 & 3 & 1 & 1 & 1 \\
\hline 1950 & 8 & 13 & 27 & 4 & 1 & 1 & & & & 1 & & & & 1 & 1 & & & & & 1 & - & & & 3 & 1 & & 2 & \\
\hline 1093, 19980 & 1110 & & & 73 & 19 & 10 & 3 & 7 & B4 & 12 & 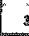 & & & 3 & 28 & $B$ & 11 & 2 & 6 & 3 & - & 2 & 5 & 8 & & 1 & & \\
\hline 1951 & 24 & 23 & 28 & 21 & 9 & 2 & & 4 & & 3 & & & & 3 & 3 & & & & & & 1 & & 2 & & & & & \\
\hline 894210891 & 134 & & & 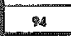 & 28 & 12 & $\sqrt{3}$ & $\pi$ & {$[18$} & 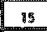 & 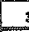 & & & 3 & 31 & 1 & 11 & 3 & 4 & 3 & . & 2 & 8 & 8 & 8 & 1 & & 1 \\
\hline 1052 & 11 & 8 & 26 & 9 & 2 & 3 & & $\overline{2}$ & 1 & 1 & & & & & 2 & & & & 1 & & 1 & 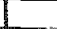 & & & & & & \\
\hline $1993-1992$ & 2045 & & & 103 & 20 & 15 & 3 & 13 & 05 & 16 & 3 & -1 & & 5 & 33 & 3 & 11 & 8 & 5 & {$\left[\begin{array}{l}3 \\
\end{array}\right.$} & 2 & 2 & 7 & $\because$ & 4 & 1 & 3 & 1 \\
\hline 1053 & II & 7 & 26 & 11 & 3 & & 2 & 1 & 4 & & & & & 1 & & & & & & & & & & & & & & \\
\hline $1993-10923$ & 158 & & & 116 & 33 & 15 & 5 & 14 & 19 & 18 & 3 & & & 6 & 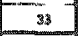 & 3 & 11 & 2 & {$[5]$} & 3 & 2 & 2 & 3 & 9 & 4 & 1 & 3 & 1 \\
\hline 1054 & 18 & 14 & 24 & 8 & 5 & 1 & & & 2 & & & & & & 10 & 3 & 2 & 4 & & 1 & & & & & & & & \\
\hline B993-19854 & & & & 122 & $x$ & 16 & 5 & 14 & 29 & 16 & 3 & & & 6 & 43 & 8 & is & 6 & 3 & 4 & 2 & 2 & 7 &. & 4 & 1 & 3 & 1 \\
\hline 1953 & 10 & 9 & 24 & $\overline{2}$ & 1 & & & & & 1 & & & & & 7 & & 2 & & & & & & 5 & & & & & \\
\hline 1983,1955 & 184 & & & 124 & 39 & 78 & 5 & 16 & 21 & 17 & {$[3$} & 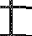 & & - & 50 & 4 & 15 & 8 & 8 & 4 & 2 & 2 & 12 &. & 4 & 1 & 3 & 1 \\
\hline 1956 & 8 & 8 & 23 & 2 & 1 & & & 1 & & & & & & & 8 & & 1 & & 1 & & & & 4 & 1 & 1 & & & \\
\hline (1993,19828 & 182 & & & 126 & 80 & 18 & 5 & 15 & 21 & 18 & 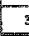 & & & 6 & 88 & 4 & 16 & $\%$ & 8 & 4 & 2 & 2 & 16 & 10 & 5 & 1 & 3 & 1 \\
\hline 1957 & 5 & 5 & 23 & 2 & & 2 & & & & & & & & & 2 & & & & 2 & & & & & 1 & & & 1 & \\
\hline 10932.1957 & 187 & & & 120 & 40 & 18 & 5 & 18 & 5 & 17 & 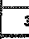 & 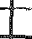 & & 8 & 98 & 4 & -16 & 6 & 8 & 4 & $2_{2}^{-}$ & 2 & 16 & $\frac{1}{11}$ & 5 & 1 & 4 & 1 \\
\hline 1958 & 5 & 5 & 22 & 3 & & 1 & & & & & 2 & & & & 2 & & & & & & & 1 & 1 & 1 & 1 & & & I \\
\hline 199321938 & 203 & & & 193 & A6 & 10 & 5 & 15 & 29 & $\sqrt{17}$ & 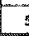 & & & 6 & $\infty$ & 4 & 16 & 6 & 8 & 4 & 2 & 3 & 18 & 12 & 6 & 1 & 4 & 1 \\
\hline 1958 & 12 & 10 & 22 & 4 & 2 & 1 & & & & 1 & & & & & 8 & & & & 1 & & & & 7 & & & & & \\
\hline 1982319898 & 215 & & & 135 & 43 & 20 & 5 & 15 & $21^{\circ}$ & 10 & 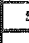 & -1 & & 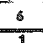 & $\infty$ & 4 & 16 & $\therefore$ & 9 & 4 & 2 & 3 & 24 & 12 & 6 & 1 & 4 & 1 \\
\hline 1960 & 4 & 4 & & ${ }^{3}$ & 2 & & & & & & & & & 1 & 1 & & & 1 & & & & & & & & & & \\
\hline 1828218900 & 219 & & & 1188 & 4 & 20 & 5 & 15 & 21 & 188 & $\underline{s}$ & & & 7 & 69 & 4 & 16 & 7 & 9 & 4 & -2 & 3 & 28 & 12 & 6 & 1 & 4 & 1 \\
\hline Trat & 210 & & & 15 & 44 & 20 & $\overline{5}$ & 15 & 21 & 78 & & & & & 8 & 57 & 6 & 7 & 97 & 4 & , & 3 & 24 & 12 & & 1 & 41 & 1 \\
\hline
\end{tabular}




\section{DEATH RATES ... AEC \& NSC PER 100,000 EMPLOYEES}

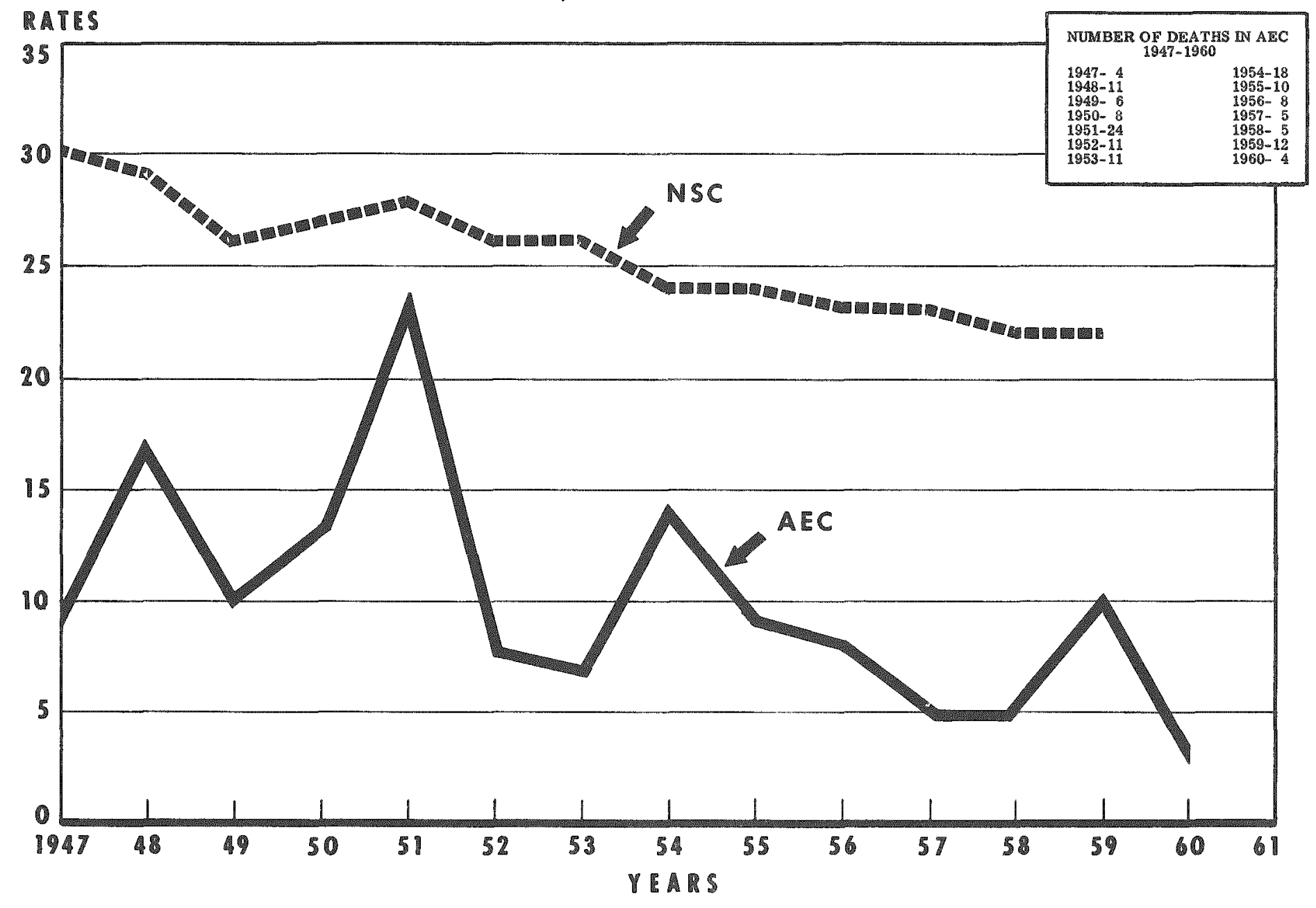

Chart 2 
Richland, Wash., April 10, $1959-$ Ref: - HS-59-10

Nalure of Accident

Workman straddling 4 in. pipe fell 50 feet.

Description of Operation

Boilermaker-rigger was tightening a $3 / 4$-in. hanger rod.

\section{Details of Accident}

Two workmen were simultaneously tightening a hanger rod into couplings, one at the steel wall of the building and the other at the 4 -in. pipe. One workman was on a bracket scaffold and using an 18-in. wrench; the other was straddiing the 4 -in. pipe and using a 10-in. pipe wrench. As the workman on the 4-in. pipe leaned on the rod while attempting to move along the pipe to the next rod, the tightened rod broke at the pipe and coupling and the workman lost his balance and fell 50 feet to the floor below, landing on reinforcing rods which pierced his arm, heart, and lungs. The rod broke due to a torsional failure.

Nature of Mnjuries or Lass

Boilermaker-rigger died instantly when he fell.

\section{FATAL FALL FROM SCAFFOLD}

Idaho Falls, Idaho, May 13, 1959 -Ref: - HS-59-14

Nature of Accident

A sheet metal worker was killed when the $5 / 2 \times 14 \mathrm{ft}$ cross section, $60 \mathrm{ft}$ high scaffold on which he was working overturned and crashed on the concrete floor.

Description of Operation

Erection of metal siding on $62 \mathrm{ft}$ doors of a hangar building.

\section{Details of Accident}

Working alone on top, the sheet metal worker had removed the tie lines which anchored the top of the scaffold to the building, and was preparing to relocate same following scaffold movement to a new position. Gusty winds of 10-26 mph were blowing against the broad side of this three section long and one section wide scaffold. The half ton weight of the overhanging 20 -in. decking on outboard brackets and the $1 / 16$-in. per foot floor slope both contributed to scaifold instability. Moves of the same type had been accomplished previously with two men (including the deceased) on top and eight men on the ground. At the top, a "runing tension line" was rigged before tie lines were released from anchor points.

Nature of Injuries or Loss

Fatal injury to sheet metal worker. 


\section{WORKMAN ELECTROCUTED}

Oak Ridge, Tenn., Aug. 7, 1959-Ref: - HS-59-25

Nature of Accident

Electrocution.

Description of operation

Wiring an arc welder into a temporary switchbox.

\section{Details of Accident}

The welding machine has been positioned under a shed adjacent to a substation transformer enclosure fence on which several temporary switchboxes were mounted.

The power cable from the welding machine was not equipped with a standard plug nor was the switchbox fitted with a 440 -volt receptacle. Thus it was necessary to wire the machine directly into the switchbor.

Before malking the hookup, the electrician examined the wiring in the welding machine but had difficulty in identifying coding colors of the individual conductors. He stripped back a section of the cable sheath exposing colors of red, black, white, and grey or greenish-grey. He decided the latter was the ground conductor and proceeded to make the switchbox hookup on that premise. The helper actually fastened the grey or greenish mgrey conductor to the ground lug in the switchbox while the electrician examined the machine.

Satisfied that the machine was ready, the electrician instructed the helper to close the switchbos door and throw the lever to the "on" position, which he did.

After some confusion as to where the "start" button was on the machine, the electrician positioned himself in front of the machine. At this time, he somehow made contact with the machine, yelled and fell across the machine, clutching at a third workman who was standing near. Although he fell a shock when the electrician grabbed him, he thought the electrician had suffered a heart attack. He started to take hold of the electrician's shirt sleeve but received another shock. He then tried looping a welding cable under the injured. Finally, as sisted by the helper, they pulled the electrician clear of the machine and placed him on a sheet of plywood brought over by a carpenter. The ground under the machine and general vicinity was wet and hot with electricity, and the machine was smoking, as observed by this third man.

The two men started giving artificial resuscitation, and the helper directed another electrician to call the ambulance, doctor, and fire department. Shortly, the helper was relieved, and went back near the machine to get his pliers, receiving a shock when he picked them up. The Electrician Shop Steward, who was with him, directed someone to get a "hot stick" and to pull the switch, when he noticed the metal wheels of the machine steaming where they were setting in water.

\section{Nature of Tnimies or Loss}

The doctor and nurse arrived with the ambulance and took charge of the injured. The doctor continued resuscitation with the mouth-to-mouth technique and administered drugs but was unable to produce any response. The electrician was pronounced dead 30 minutes after the accident and taken to the hospital.

\section{Remarks}

Subsequent investigation revealed that one wire originating at the equipment ground terminal inside the welding machine had been run to a phase lug in the machine and was connected to the ground lug in the switchbox. One of three 60 -amp. fuses in the switchbox had blown.

Upon examination of the color coded wires at both ends of the cable, it was found that, although badiy faded, the black and red were identifiable. The other two (one of which was the ground wire), which presumably were coded white and grey, were difficult, if not impossible, to distinguish as to which was which. 
It was further determined that no attempt was made to "ring out"* the conductors in the cable to ascertain exactly which one was a grounding conductor.

In the confusion, apparently no one thought to turn off the power to the machine.

An electrical contractor superintendent reported that the machine power cable had previously been equipped with a 4-prong plug to fit the 440-volt receptacle sockets located at various locations on a previous job on the site; and that the deceased would have had to remove this plug from the end of the cable before making a connection directly into the switchbox.

\section{EXPLOSIVES EXPLOSION}

Los Alamos, N. Mex., Oct. 14, 1959-Ref: - HS-59-32

Nature of Accident

Explosion.

Description of Operation

Disposing of scrap and waste explosives at burning pad.

Details of Accident

Four men had backed an explosives scrap truck into a burning pad enclosure for unloading. The explosives were to be burned as a means of disposal. During the unloading of the explosives, an accidental detonation occurred. The exact cause of the initiation is unknown.

Nature of Injuries or Loss

Four men were fatally injured.

\section{MOTOR VEHICLE ACCIDENT}

Mercury, Nev., Dec. 2, 1959-Ref: - HS-59-39

Nature of Accident

Motor vehicle.

Description of Operation

Driving a motor vehicle.

Details of Accident

An employee driving a Government vehicle (traveling northwest) collided with a station wagon (traveling southeast). The driver of the station wagon pulled out to pass a large van truck traveling in the same direction. The vehicles collided at a point directly opposite the cab of the van truck.

Nature of Injuries or Loss

Employee in Government car was fatally injured. The other driver received lacerations of face and head and other minor contusions.

* Term used by electricians for instrument testing of continuity and identification of conductors where this cannot be ascertained by visual check. 


\section{SUFFOCATION}

Canoga Park, Calif., Dec. 18, 1959-Ref: - HS-59-41

Vature of Accident

Asphyziation.

Description of Operation

Inspecting a sodium pump loop.

Delails of Accident

Information was being sought in connection with the recent failure of the sodium pump (see drawing) while being tested. To minimize oxidation of sodium residue on interior walls of the casing, argon gas was fed into it by tubing through a wooden cover plate.

Normal procedure for entering the casing prescribed that personnel be lowered into it by a slow-moving hoist to which they were attached by a body safety harness, and wearing an oxygen mask (self-contained oxygen breathing apparatus).

It is reported that the inspector was wearing only a filter respirator face mask and that he rode the hoist hook down by standing on it. He collapsed after a short time at the bottom of the casing.

A fellow inspector at the top is reported to have shouted for help which brought the welder running up the stairs leading to the platform at the top of the casing.

The welder fashioned a rope body harness and had himself lowered into the casing on the electric hoist. (As reported, he wore no mask at all). While being lowered, he collapsed and slipped out of the rope harness.

Oxygen masks and body safety harnesses designed for the purpose were obtained, and two employees, properly equipped with these, were lowered into the casing. They were hoisted out, with first the welder, and then the inspector, in their arms. The inspector was cyanotic when removed and had no detectable pulse. Efforts were made to administer oxygen on the spot.

It was estimated that the inspector was in the casing about 15 minutes and the welder on the order of seven or eight minutes before they were lifted out.

\section{Nature of Injuries or Loss}

A reactor-assemblyman-inspector died from suffocation shortly after entering the pump case. As of January 25,1960 , information indicates that the senior reactor welder is coming along satisfactorily.

\section{Remarks}

The primary cause of these two accidents appears to have been the failure on the part of both men to wear proper breathing equipment appropriate to an inert gas. The reactorassemblyman wore a filter-type respirator which is designed to filter out toxic and noxious particulate matter in a breathing atmosphere. The filter respirator does not filter out gases, nor does it provide a source of oxygen if no oxygen is present in the breathing atmosphere. Hence, this respirator could give no protection to the inspector. The senior reactor welder's action in descending without any protection at all was the result of an emotional reaction and not based on a calm and logical deliberation. A contributing cause was failure to wear a safety harness or belt which was available and convenient or to wear a lifeline, for which rope was on the sile.

The preventive measures which will be implemented and enforced are:

1. It will be the responsibility of the immediate supervisor to orient and inform all persons performing hazardous work as to the entire scope of hazards and/or materials to be encountered in an operation and to insure, by proper supervision, that prescribed safety measures are carried out. 


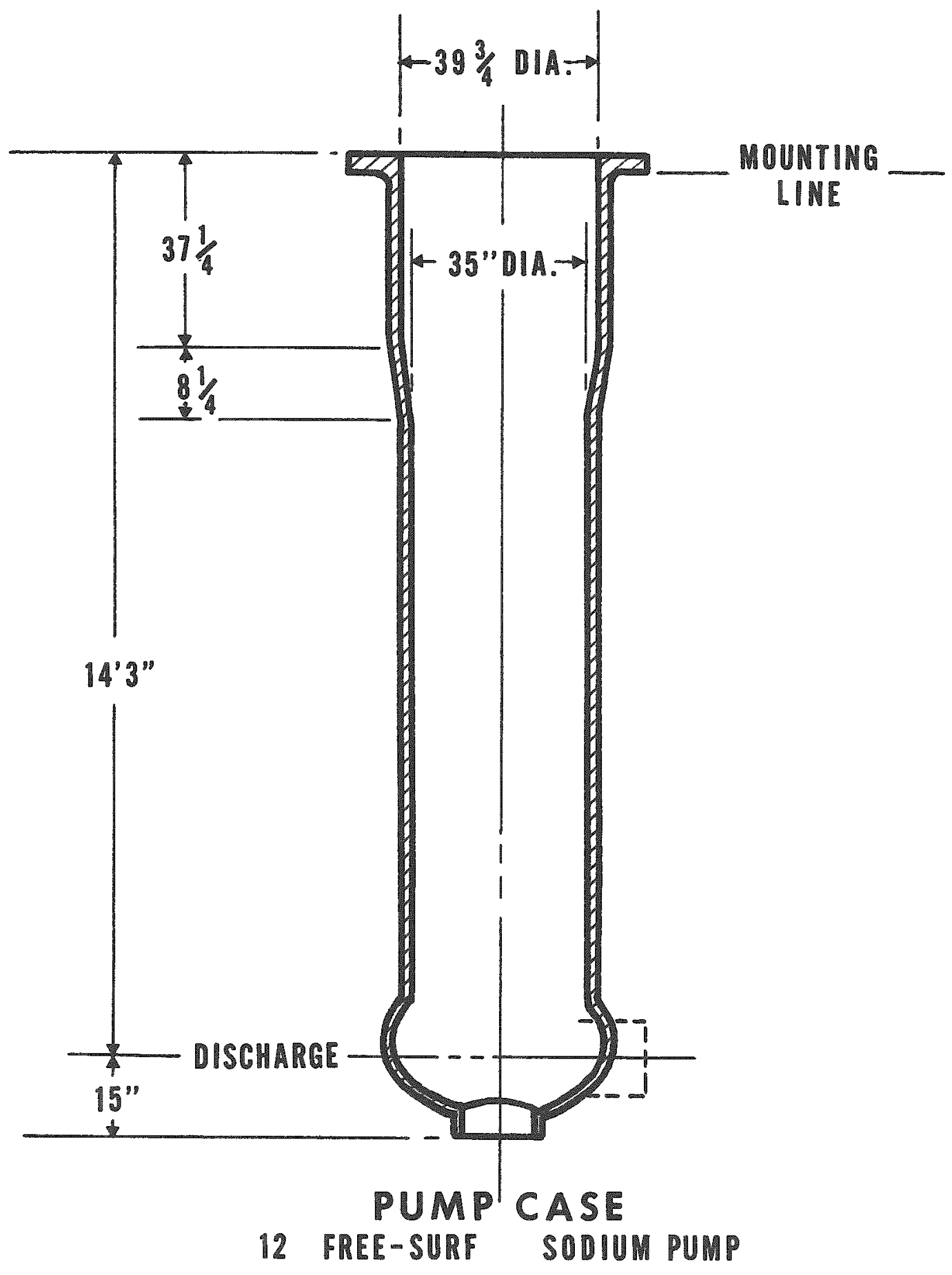


2. All future operations requiring personnel to enter tanks or areas devoid of oxygen or provided with any inert gases will require the presence of a completely equipped fireman to stand by in readiness to effect a rescue.

3. All inert and/or toxic gas containers or areas will be posted and a Safe Work Permit will be required prior to performing work.

\section{FAILURE OF A CABLE CAUSE OF DEATH}

Albuquerque, N. Mex., Dec. 23, 1959-Ref: - HS-59-42

Nature of Accident

Two pendant lines supporting the jib section (boom of a mobile crane) broke, allowing a hopper bucket to fall on a construction employee.

\section{Description of Operation}

Placing concrete with mobile crane at construction site.

\section{Details of Accident}

During concrete placement operations, an employee was killed by a falling concrete hopper bucket. The bucket was being handled by a mobile crane when one of the two pendant lines supporting the jib section broke. The pendant lines support the $30 \mathrm{ft}$ jib boom, which is an extension of the $50 \mathrm{ft}$ main hoisting boom.

The broken pendant line caused the jib section to twist, allowing the loaded one cubic yard bucket to fall on the employee.

The employee was on a scaffolding receiving the bucket (with helper) and discharging the concrete into the forms.

Nature of Injuries or Loss

Employee was killed when a one cubic yard bucket of concrete fell on him.

\section{DROWNING}

Eniwetok Proving Ground, Jan. 29, 1960-Ref: - HS-60-4

Nature of Accident

Professional skindiver drowned while performing assigned duties.

\section{Description of Operation}

Placing dynamite charges ( 4 to 5 feet under water) to sink LCU hull for use as a breakwater to prevent erosion of the beach.

\section{Details of Accident}

Explosives were used to blow holes in the bottom of the craft to sink it and allow the surge to wash sand into the hull to hold it in place. The shot failed to detonate and skindiver " $\mathrm{A}$ " placed a booster charge. The diver "A" then surfaced and began swimming around the hull. A supervisor on LCU checked around and did not see "A". At this time an attempt was made to locate the diver ("A"). Another diver, "B", after seeing no tracks to beach, put on his mask and dove down to see if he could find "A". He saw him in an air pocket and pulled him out.

Nature of Injuries or Loss

Death by drowning. 


\section{FATAL ACCIDENT IN CAFETERIA KITCHEN}

Mercury, Nev., March 18, 1960-Ref: - HS-60-12

Nature of Accident

A cafeteria employee was scalded by hot broth spilled on face and entire front of his body when he slipped.

Description of Operation

Working in a cafeteria kitchen.

Delails of Accident

Two cafeteria employees, "A" and "B", proceeded to empty a 20 -gallon container of hot soup stock into a steam kettle.

The pot was raised to the lip of the steam kettle, which was 42 in. from the floor, when the foot of "A" slipped and he fell to the floor. The hot soup stock poured onto him, causing first and second degree burns over approximately $20 \%$ of his body.

Nahre of Injury

Employee "A" died on April 7 from uremia, which arose as a complication from burns received from the accident.

\section{FATAL FALL}

Cambridge, Mass., April 13, 1960-Ref:-HS-60-13

Nature of Accident

An employee fell from a 30-in. wide ground level wall to a concrete floor $20 \mathrm{ft}$ below.

Description of Operation

Straightening reinforcing rod with a length of pipe.

\section{Details of Accident}

In order to construct an addition to the experiment building, a concrete foundation wall was extended around the perimeter of the new building area. An employee, working on a 34 -in. surface of the wall was straightening one of several $6 \% \frac{3}{4}$-in. reinforcing rods with a $6 \mathrm{ft}$ length of $1 \frac{1 / 2}{2}$-in. diameter pipe used as a lever. The rod being straightened, by the employee, broke, and he fell backward onto a concrete floor below.

\section{Nature of Injuries or Loss}

The cause of death was a fractured cervical vertebrae and a crushed chest associated with multiple fractures received in the fall. 


\section{PAINTER FALLS IN FATAL PLUNGE}

Idaho Falls, Idaho, August 31, 1960-Ref: - HS-60-25

Nature of Accident

Fatal fall from an upper structure of a plant.

Description of Operation

Painting the railing, ladders, and cages on the top portions of the cement silos.

Details of Accident

Without an eyewitness to the origin of the fatal fall or other evidence indicating the precise circumstances, the cause is unknown.

Nature of Inimrics or Loss

While a painter was painting the handrail around a silo, he suffered fatal injuries when he fell $69 \mathrm{ft}$. 